Review

\title{
A review of the microbiological hazards of dairy products made from raw milk
}

\author{
C. Verraes ${ }^{\text {a, *}}$, G. Vlaemynck ${ }^{\text {b }}$, S. Van Weyenberg ${ }^{\text {b }}$, L. De Zutter ${ }^{\text {c, d }}$, G. Daube ${ }^{\text {c, e }}$, \\ M. Sindic ${ }^{\text {c, f }}$, M. Uyttendaele ${ }^{\text {c, g, }}$, L. Herman ${ }^{\text {b, c }}$ \\ a Staff Direction for Risk Assessment, DG Control Policy, Federal Agency for the Safety of the Food Chain (FASFC), Kruidtuinlaan 55, 1000 Brussels, Belgium \\ ${ }^{\mathrm{b}}$ Institute of Agricultural and Fisheries Research (ILVO), Brusselsesteenweg 370, 9090 Melle, Belgium \\ c Scientific Committee, Federal Agency for the Safety of the Food Chain (FASFC), Kruidtuinlaan 55, 1000 Brussels, Belgium \\ ${ }^{\mathrm{d}}$ Faculty of Veterinary Medicine, Ghent University, Salisburylaan 133, 9820 Merelbeke, Belgium \\ e Faculty of Veterinary Medicine, University of Liège, Boulevard de Colonster 20, 4000 Liège, Belgium \\ ${ }^{\mathrm{f}}$ Gembloux Agro-bio Tech, University of Liège, Passage des Déportés 2, 5030 Gembloux, Belgium \\ ${ }^{g}$ Faculty of Bioscience Engineering, Ghent University, Coupure Links 653, 9000 Ghent, Belgium
}

\section{A R T I C L E I N F O}

\section{Article history:}

Received 7 April 2015

Received in revised form

21 May 2015

Accepted 25 May 2015

Available online 14 June 2015

\begin{abstract}
A B S T R A C T
This review concentrates on information concerning microbiological hazards possibly present in raw milk dairy products, in particular cheese, butter, cream and buttermilk. The main microbiological hazards of raw milk cheeses (especially soft and fresh cheeses) are linked to Listeria monocytogenes, verocytotoxin-producing Escherichia coli (VTEC), Staphylococcus aureus, Salmonella and Campylobacter. L. monocytogenes, VTEC and S. aureus have been identified as microbiological hazards in raw milk butter and cream albeit to a lesser extent because of a reduced growth potential compared with cheese. In endemic areas, raw milk dairy products may also be contaminated with Brucella spp., Mycobacterium bovis and the tick-borne encephalitis virus (TBEV). Potential risks due to Coxiella burnetii and Mycobacterium avium subsp. paratuberculosis (MAP) are discussed. Pasteurisation ensures inactivation of vegetative pathogenic microorganisms, which increases the safety of products made thereof compared with dairy products made from raw milk. Several control measures from farm to fork are discussed.
\end{abstract}

(C) 2015 Elsevier Ltd. All rights reserved.

\section{Contents}

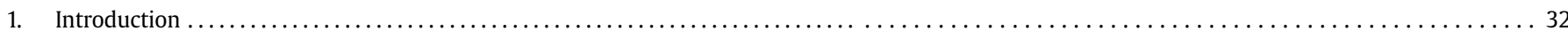

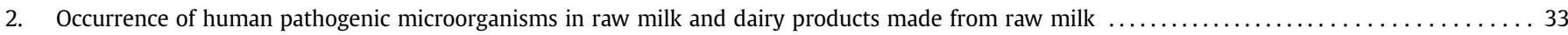

3. Reported human cases and outbreaks due to the consumption of dairy products made from raw milk ........................ 33

4. Growth and survival of pathogenic microorganisms during production and storage/ripening of dairy products made from raw milk .......... 38

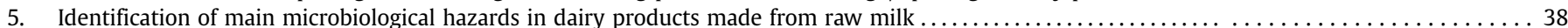

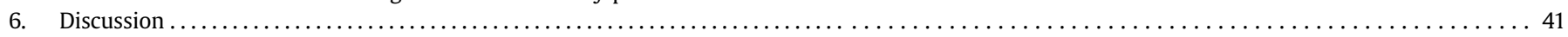

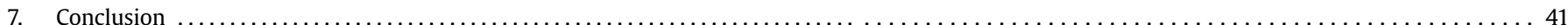

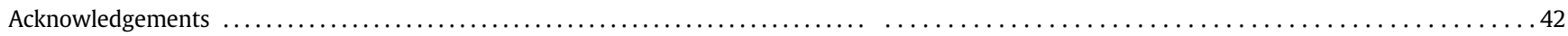

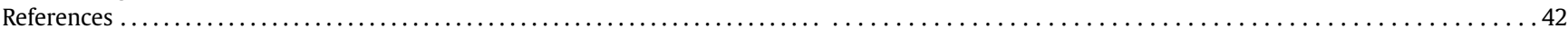

\footnotetext{
* Corresponding author. Tel.: +3222118700.

E-mail address: claire.verraes@favv.be (C. Verraes).
}

\section{Introduction}

Consumers' attitudes show a trend towards increased consumption of foods that are not or only minimally processed such as raw milk and dairy products made from raw milk. Cheeses made from raw cow, sheep and goat milk are the most frequently 
consumed type of dairy products made from raw milk; however, other types of dairy products made from raw milk are also consumed such as mozzarella made from raw buffalo milk, as well as raw milk butter made from cow milk. The consumption of raw milk can hold a risk for the consumer, due to the possible presence of human pathogenic microorganisms. The risks and benefits of the consumption of raw cow milk were described in a review by Claeys et al. (2013) and the nutritional and health benefits of the consumption of raw milk from animal species other than cows were described in a review by Claeys et al. (2014). The microbiological hazards of raw milk from animal species other than cows were described in a review by Verraes et al. (2014). Also EFSA evaluated the public health risk from the consumption of raw drinking milk (EFSA, 2015).

In the present review, a collation is made of available information in the scientific literature concerning the microbiological hazards of dairy products made from raw milk, in particular cheese, butter, cream and buttermilk. Dairy products made from raw milk from cows, sheep and goats are taken into account. Dairy products made from raw milk from other animal species are less relevant in Europe, with the exception of mozzarella made from raw buffalo milk. Only zoonotic human pathogenic microorganisms and pathogens originating from the environment have been taken into consideration. Pathogenic agents originating from human contamination due to human illness, e.g., Salmonella Typhi, Shigella spp. and noroviruses are not covered in this review.

\section{Occurrence of human pathogenic microorganisms in raw milk and dairy products made from raw milk}

In general, pathogenic microorganisms can contaminate raw milk in two ways. The first way is an endogenous contamination where the milk is contaminated by a direct transfer from the blood (systemic infection) to the milk or via an infection in the udder called mastitis. The second way is an exogenous contamination, where the milk is contaminated during or after milking by the faeces, the exterior of the udder and teats, the skin, the environment, etc.

Based on recent review documents (Claeys et al., 2013; EFSA, 2015; Sci Com, 2011, 2013; Verraes et al., 2014), the following human pathogenic microorganisms are considered as the main microbiological hazards associated with raw milk consumption from cows, goats and sheep: Bacillus cereus, Campylobacter coli and Campylobacter jejuni, enterotoxin-producing Staphylococcus aureus, Helicobacter pylori, human pathogenic verocytotoxin-producing Escherichia coli (VTEC), human pathogenic Yersinia, Leptospira, Listeria monocytogenes, Salmonella spp., Streptococcus agalactiae, Streptococcus equi subsp. zooepidemicus, Clostridium botulinum, Brucella spp., Mycobacterium bovis, Cryptosporidium parvum and Toxoplasma gondii. Some microbiological hazards are indicated as hypothetical because they are still not confirmed, but have the hypothetical potential to be pathogenic for humans (Mycobacterium avium subsp. paratuberculosis; MAP) or to be foodborne (Coxiella burnetii).

Limited systematic data were available on prevalences of human pathogenic microorganisms in dairy products made from raw milk. In a baseline study (EFSA, 2013b) performed at a European level, 1 sample from 476 raw milk cheese samples exceeded $100 \mathrm{cfu} \mathrm{g}^{-1}$ for L. monocytogenes. The EU summary report mentioned that noncompliance of $L$. monocytogenes primarily occurred in soft and semi-soft cheeses made from raw or low heat-treated cows' milk (EFSA \& ECDC, 2015). In addition, studies in the scientific literature describing detection frequencies of human pathogenic microorganisms in dairy products made from raw milk provide an indication of prevalences. Data of such frequencies of occurrence were collected for Europe and are shown in Table 1, where the detection frequency, the type of food, the method of analysis and the country are given.

Frequencies of occurrence were found for several raw milk cheeses, butter and cream. No frequencies were found for buttermilk made from raw milk as such products are less often produced. No Salmonella has been detected in any tested samples of raw milk cheeses, butter and cream with the exception of one publication where the prevalence in cheese was $4.3 \%$ ( $\mathrm{n}=70$ samples; Almeida et al., 2007). Concerning VTEC in raw milk cheeses, E. coli strains with virulence genes are detected with frequencies between 0 and $55.3 \%$. Farrokh et al. (2013) stated that the prevalence of $v t x$ genes, detected by PCR, does not necessarily reflect the occurrence of a viable $E$. coli isolate containing those genes. VTEC was also detected in butter (Messelhäusser, Beck, Gallien, Schalch, \& Busch, 2008). As illustrated in Table 1, L. monocytogenes was detected in raw milk cheeses, butter and cream with frequencies varying between 0 and $41.9 \%, 3.6$ and $29.9 \%$, and 0.7 and $8.3 \%$ respectively, although in some cases the numbers were lower than $100 \mathrm{cfu} \mathrm{g}^{-1}$. Of 70 cheese samples, $11.4 \%$ were positive for $L$. monocytogenes per $25 \mathrm{~g}$, whereby $1.4 \%$ contained counts higher than 200 cfu g $^{-1}$ and $10.0 \%$ lower than $100 \mathrm{cfu} \mathrm{g}^{-1}$ (Almeida et al., 2007). Of 474 cheese samples and 519 butter samples, respectively, $0.6 \%$ and $0.2 \%$ of the samples that were taken in Belgium by the sector of small cheese producers in the Walloon region had counts higher than $100 \mathrm{cfu} \mathrm{g}^{-1}$ (Sci Com, 2015). No Campylobacter were detected in 199 tested raw milk cheeses, which contrasts the higher reporting in raw milk (0-12\%) (EFSA, 2015; Verraes et al., 2014). As indicated in Table 1, S. aureus was found in raw milk products with frequencies between 5 and 100\% in cheeses, and between 1.6 and $20.3 \%$ in butter, but the possibility of the strains to produce enterotoxins varies and the share of such strains is difficult to deduce from the available information. Jørgensen, Mørk, and Rørvik (2005) also detected S. aureus in sour cream. B. cereus was detected in $28 \%$ of 25 samples of cheeses made from raw milk of several animal species. All strains were able to produce enterotoxins (Williams \& Withers, 2010). MAP was detected in 4.2 and $20 \%$ of raw milk cheese samples using PCR (Stephan, Schumaher, Tasara, \& Grant, 2007; Williams \& Withers, 2010). C. burnetii was detected with PCR in $57.0 \%$ of unpasteurised cheese samples and in one of two cream samples, but the relation of these PCR results with the presence of infectious strains is not clear (Eldin, Angelakis, Renvoisé, \& Raoult, 2013).

\section{Reported human cases and outbreaks due to the consumption of dairy products made from raw milk}

The development of a disease after consumption of contaminated dairy products made from raw milk depends on several factors such as the pathogenicity of the strain, the number of ingested microorganisms, the physiological state of the microorganism, the health condition of the consumer at the moment of ingestion, etc. Persons belonging to the YOPI group (young, old, pregnant, immunodeficient) have a higher risk of infection for certain pathogens such as L. monocytogenes and healthy persons can also be infected. The likelihood of developing a disease follows a dose-response curve with a higher number of cells increasing the chance of developing a disease. This relationship was categorised by the EFSA BIOHAZ Panel in the framework of a risk ranking exercise of foods of non-animal origin as follows: score 1 stands for a dose-response curve where the pathogen has to grow to high numbers (often higher than $5 \log \mathrm{cfu} \mathrm{g}^{-1}$ ) to produce toxins and cause illness; score 2 stands for a dose-response curve where the pathogen must grow to cause illness; and score 3 stands for a dose-response curve where the pathogen can cause illness in low numbers (Da Silva et al., 2015; EFSA, 2013a). Salmonella, 
Table 1

Reported frequencies of occurrence of human pathogenic microorganisms in/on dairy products made from raw milk in Europe. ${ }^{a}$

\begin{tabular}{|c|c|c|c|c|c|}
\hline $\begin{array}{l}\text { Dairy product made } \\
\text { from raw milk }\end{array}$ & $\begin{array}{l}\text { Frequency of } \\
\text { occurrence (\%) }\end{array}$ & $\begin{array}{l}\text { Number of } \\
\text { samples }\end{array}$ & Comments & Country & References \\
\hline \multicolumn{6}{|l|}{ Salmonella } \\
\hline \multirow[t]{8}{*}{ Cheese } & 0.0 & 71 & & Belgium & $\begin{array}{l}\text { De Reu, Debeuckelaere, Botteldoorn, De } \\
\text { Block, and Herman (2002) }\end{array}$ \\
\hline & 0.0 & 20 & & Belgium & De Reu, Grijspeerdt, and Herman (2004) \\
\hline & 0.0 & 334 & & Germany & $\begin{array}{l}\text { Hahn, Walte, Coenen, and Teufel } \\
\text { (1999a) }\end{array}$ \\
\hline & 0.0 & 75 & & Ireland & Coveney, Fitzgerald, and Daly (1994) \\
\hline & 4.3 & 70 & & Portugal & Almeida et al. (2007) \\
\hline & 0.0 & 25 & & Scotland & Williams and Withers (2010) \\
\hline & 0.0 & 429 & & Belgium & DiversiFerm (pers. comm.) \\
\hline & 0.0 & 582 & & Belgium & FASFC (pers. comm.) \\
\hline \multirow[t]{3}{*}{ Butter } & 0.0 & 64 & & Belgium & De Reu et al. (2004) \\
\hline & 0.0 & 518 & & Belgium & DiversiFerm (pers. comm.) \\
\hline & 0.0 & 192 & & Belgium & FASFC (pers. comm.) \\
\hline Cream & 0.0 & 132 & & Belgium & FASFC (pers. comm.) \\
\hline \multicolumn{6}{|c|}{ Verocytotoxin-producing Escherichia coli (VTEC) } \\
\hline \multirow[t]{31}{*}{ Cheese } & 5.6 & 71 & $\begin{array}{l}\text { IMS, VIDAS O157 } \\
\text { assay and PCR }\end{array}$ & Belgium & De Reu et al. (2002) \\
\hline & 0.0 & 20 & IMS, VIDAS 0157 & Belgium & De Reu et al. (2004) \\
\hline & & & assay and PCR & & \\
\hline & 0.0 & 334 & $1.5 \%$ VTEC & Germany & Hahn et al. (1999a) \\
\hline & 4.0 & 25 & $\begin{array}{l}\text { Enrichment; } 1 \text { stx2- } \\
\text { positive strain }\end{array}$ & Italy & Volponi et al. (2012) \\
\hline & 13.1 & 1039 & PCR & France & $\begin{array}{l}\text { Vernozy-Rozand, Montet, Berardin, } \\
\text { Bavai, and Beutin (2005) }\end{array}$ \\
\hline & 5.7 & 1502 & PCR & Switzerland & Zweifel et al. (2010) \\
\hline & 0.0 & 739 & IMS & Scotland & $\begin{array}{l}\text { Coia, Johnston, Steers, and Hanson } \\
\text { (2001) }\end{array}$ \\
\hline & 8.9 & 180 & - Vero cell assay & France & Fach et al. (2001) \\
\hline & 30.6 & & - PCR-ELISA & & \\
\hline & 4.8 & 83 & Isolation & Spain & Caro and García-Armesto (2007) \\
\hline & 30.4 & 112 & - PCR-ELISA & Italy & Auvray, Lecureuil, Dilasser, Taché, and \\
\hline & 27.7 & & - RT-PCR & & Derzelle (2009) \\
\hline & 2.7 & & - Colony hybridisation & & \\
\hline & 4.5 & 143 & - PCR vtx1 gene & Italy & Civera et al. (2007) \\
\hline & 3.8 & & - PCR $v t x 2$ gene & & \\
\hline & 0.8 & & - PCR eae gene & & \\
\hline & 2.1 & & - PCR ehxA gene & & \\
\hline & 0.0 & & - Isolation & & \\
\hline & 0.0 & 1313 & $\begin{array}{l}\text { Isolation of } E \text {. coli } 0157 ; \\
\text { also butter }\end{array}$ & Italy & Conedera et al. (2004) \\
\hline & 4.9 & -796 & - PCR & Switzerland & Stephan et al. (2008) \\
\hline & 41.0 & -39 & - Non-0157 VTEC strains & & \\
\hline & 0.0 & 70 & IMS & Portugal & Almeida et al. (2007) \\
\hline & 29.8 & 400 & - PCR $v t x$ gene & France & Madic et al. (2011) \\
\hline & 37.3 & & - PCR eae gene & & \\
\hline & 55.3 & & - At least one of 026 & & \\
\hline & 6.5 & & 0103, 0111, 0145 and & & \\
\hline & & & $\begin{array}{l}\text { O157 genetic markers } \\
\text { - Combinations of above }\end{array}$ & & \\
\hline & 0.0 & 25 & Isolation of $E$. coli 0157 & Scotland & Williams and Withers (2010) \\
\hline & 10.0 & 10 & Also butter & Germany & Messelhäusser et al. (2008) \\
\hline & 0.8 & 1042 & PCR & Belgium & FASFC (pers. comm.) \\
\hline \multirow[t]{3}{*}{ Butter } & 0.0 & 64 & IMS, VIDAS 0157 & Belgium & De Reu et al. (2004) \\
\hline & & & assay and PCR & & \\
\hline & 0.0 & 366 & PCR & Belgium & FASFC (pers. comm.) \\
\hline Cream & 0.0 & 131 & PCR & Belgium & FASFC (pers. comm.) \\
\hline \multicolumn{6}{|l|}{ Listeria monocytogenes } \\
\hline \multirow[t]{9}{*}{ Cheese } & 0.0 & 55 & & Sweden & Rosengren et al. (2010) \\
\hline & 0.8 & 122 & & Norway & $\begin{array}{l}\text { Jakobsen, Heggebø, Sunde, and } \\
\text { Skjervheim (2011) }\end{array}$ \\
\hline & 2.8 & 71 & & Belgium & De Reu et al. (2002) \\
\hline & 0.0 & 20 & & Belgium & De Reu et al. (2004) \\
\hline & 2.4 & 334 & & Germany & Hahn et al. (1999a) \\
\hline & 0.0 & 17 & & Ireland & Coveney et al. (1994) \\
\hline & 11.4 & 70 & $\begin{array}{l}1.4 \%>2.3 \log \mathrm{cfu} \mathrm{g}^{-1} \\
10.0 \%<2 \log \mathrm{cfu} \mathrm{g}^{-1}\end{array}$ & Portugal & Almeida et al. (2007) \\
\hline & 19.0 & 42 & & Italy & $\begin{array}{l}\text { Rantsiou, Alessandria, Urso, Dolci, and } \\
\text { Cocolin (2008) }\end{array}$ \\
\hline & 0.0 & 252 & & Portugal & $\begin{array}{l}\text { Kongo, Malcata, Ho, and Wiedmann } \\
\text { (2006) }\end{array}$ \\
\hline
\end{tabular}


Table 1 (continued)

\begin{tabular}{|c|c|c|c|c|c|}
\hline $\begin{array}{l}\text { Dairy product made } \\
\text { from raw milk }\end{array}$ & $\begin{array}{l}\text { Frequency of } \\
\text { occurrence (\%) }\end{array}$ & $\begin{array}{l}\text { Number of } \\
\text { samples }\end{array}$ & Comments & Country & References \\
\hline & 0.0 & 51 & & Spain & Arrese and Arroyo-Izaga (2012) \\
\hline & 4.0 & 25 & & Scotland & Williams and Withers (2010) \\
\hline & 41.9 & 31 & & Sweden & Loncarevic et al. (1995) \\
\hline & 0.0 & 230 & & Austria & Schoder et al. (2011) \\
\hline & 12.2 & 474 & $0.6 \%>2 \log \mathrm{cfu} \mathrm{g}^{-1}$ & Belgium & DiversiFerm (pers. comm.) \\
\hline & 6.0 & 901 & & Belgium & FASFC (pers. comm.) \\
\hline \multirow[t]{4}{*}{ Butter } & 18.7 & 64 & & Belgium & De Reu et al. (2004) \\
\hline & 29.9 & 519 & $0.2 \%>2 \log \mathrm{cfu} \mathrm{g}^{-1}$ & Belgium & DiversiFerm (pers. comm.) \\
\hline & 12.4 & 259 & & Belgium & $\begin{array}{l}\text { De Reu and Herman (2004); De Reu, } \\
\text { Herman, De Boosere, and De Ville } \\
\text { (2006, 2007); De Reu, Herman, and De } \\
\text { Ville (2008) }\end{array}$ \\
\hline & 3.6 & 361 & & Belgium & FASFC (pers. comm.) \\
\hline \multirow[t]{4}{*}{ Cream } & 5.0 & 20 & & Belgium & De Reu and Herman (2004) \\
\hline & 8.3 & 60 & & Croatia & $\begin{array}{l}\text { Frece, Markov, Čvek, Kolarec, and Delaš } \\
\text { (2010) }\end{array}$ \\
\hline & 4.2 & 48 & & England \& Wales & Greenwood et al. (1991) \\
\hline & 0.7 & 134 & & Belgium & FASFC (pers. comm.) \\
\hline \multicolumn{6}{|l|}{ Campylobacter } \\
\hline \multirow[t]{3}{*}{ Cheese } & 0.0 & 66 & & Ireland & Whyte et al. (2004) \\
\hline & 0.0 & 10 & & Germany & Messelhäusser et al. (2008) \\
\hline & 0.0 & 123 & & Belgium & FASFC (pers. comm.) \\
\hline \multicolumn{6}{|l|}{ Staphylococcus aureus } \\
\hline \multirow[t]{9}{*}{ Cheese } & 69.0 & 55 & $\begin{array}{l}\text { Coagulase-positive } \\
\text { staphylococci; } 10.9 \%>5 \\
\log \text { cfu }^{-1} ; 0 \% \text { enterotoxins }\end{array}$ & Sweden & Rosengren et al. (2010) \\
\hline & 67.5 & 122 & Average of cheese stages & Norway & Jakobsen et al. (2011) \\
\hline & 19.7 & 71 & $\begin{array}{l}>3 \log \mathrm{cfu} \mathrm{g}^{-1} ; 7.1 \%(14) \\
\text { Enterotoxins }\end{array}$ & Belgium & De Reu et al. (2002) \\
\hline & 5.0 & 20 & $0 \%$ Enterotoxins & Belgium & De Reu et al. (2004) \\
\hline & 13.1 & 245 & $>4 \log \mathrm{cfu} \mathrm{g}^{-1}$ & Germany & $\begin{array}{l}\text { Hahn, Walte, Coenen, and Teufel } \\
\text { (1999b) }\end{array}$ \\
\hline & 100.0 & 33 & 42.4\% Enterotoxins & Italy & Cremonesi et al. (2007) \\
\hline & 80.4 & 46 & $\begin{array}{l}\text { Average of cheese stages; } \\
100 \% \text { enterotoxins }\end{array}$ & Italy & Poli et al. (2007) \\
\hline & 36.0 & 25 & $\begin{array}{l}7 \text { of } 18 \text { Examined strains } \\
\text { from } 2 \text { cheeses able } \\
\text { to produce enterotoxin } C\end{array}$ & Scotland & Williams and Withers (2010) \\
\hline & 8.3 & 737 & $>5 \log \mathrm{cfu} \mathrm{g}^{-1}$ & Belgium & FASFC (pers. comm.) \\
\hline \multirow[t]{2}{*}{ Butter } & 1.6 & 64 & $0 \%$ Enterotoxins & Belgium & De Reu et al. (2004) \\
\hline & 20.3 & 281 & & Belgium & FASFC (pers. comm.) \\
\hline \multicolumn{6}{|l|}{ Bacillus cereus } \\
\hline \multirow[t]{2}{*}{ Cheese } & 28.0 & 25 & $100 \%$ Enterotoxins & Scotland & Williams and Withers (2010) \\
\hline & 0.0 & 3 & & Belgium & FASFC (pers. comm.) \\
\hline \multicolumn{6}{|c|}{ Mycobacterium avium subsp. paratuberculosis } \\
\hline \multirow[t]{2}{*}{ Cheese } & 4.2 & 143 & PCR; no viable cells & Switzerland & Stephan et al. (2007) \\
\hline & 20.0 & 25 & PCR & Scotland & Williams and Withers (2010) \\
\hline \multicolumn{6}{|l|}{ Coxiella burnetii } \\
\hline Cheese & 57.0 & 68 & & France & Eldin et al. (2013) \\
\hline Butter & 0.0 & Not given & & France & Eldin et al. (2013) \\
\hline Cream & 50.0 & 2 & & France & Eldin et al. (2013) \\
\hline
\end{tabular}

a Abbreviations are: IMS, immunomagnetic separation; PCR, polymerase chain reaction; PCR-ELISA, polymerase chain reaction enzyme-linked immunosorbent assay.

Campylobacter, VTEC and the tick-borne encephalitis virus (TBEV) were in the framework of the present study allocated a score 3; L. monocytogenes, Brucella, M. bovis and pathogenic species of Streptococcus have to grow to cause illness and have score 2; and $S$. aureus and B. cereus have to grow to numbers of several log units to be able to produce sufficient toxins to cause illness and therefore they have a score of 1 . For MAP and $C$. burnetii the foodborne and zoonotic potential is not known.

The consumption of dairy products made from raw milk has already caused several human cases and outbreaks. In Table 2, a non-exhaustive list is shown of reported human cases and outbreaks in Europe, the United States and Canada related to the consumption of dairy products made from raw milk found in scientific literature or reported by official organisations. Only outbreaks due to the consumption of raw milk cheeses were found and one outbreak was ascribed to the consumption of raw milk cream linked to infection with E. coli O157:H7 (CDSC, 1998a). Outbreaks due to the consumption of raw milk butter or buttermilk were not found. From a report from EFSA (EFSA \& ECDC, 2014), it seems that in 2012 no outbreaks were reported in the EU due to the 
Table 2

Reported human cases and outbreaks in Europe, the United States and Canada due to the consumption of dairy products made from raw milk.

\begin{tabular}{|c|c|c|c|c|c|}
\hline Pathogenic agent & $\begin{array}{l}\text { Dairy product made from } \\
\text { raw milk }\end{array}$ & Country & Year & Cases & References \\
\hline Salmonella enteric Muenster & $\begin{array}{l}\text { Cheddar cheese from } \\
\text { unpasteurised milk }\end{array}$ & Canada & 1982 & Not given & $\begin{array}{l}\text { D'Aoust, Warburton, } \\
\text { and Sewell (1985); van } \\
\text { Cauteren et al. (2009) }\end{array}$ \\
\hline Salmonella Typhimurium PT10 & $\begin{array}{l}\text { Cheddar cheese from } \\
\text { unpasteurised milk }\end{array}$ & Canada & 1984 & $>1700$ confirmed cases & D'Aoust et al. (1985) \\
\hline Salmonella & Farm raw milk cheese & Finland & 1985 & 35 cases & $\begin{array}{l}\text { Huchot, Bohnert, Cerf, } \\
\text { Farrokh, and Lahellec } \\
\text { (1993) }\end{array}$ \\
\hline Salmonella Typhimurium & $\begin{array}{l}\text { Raw milk vacherin mont } \\
\text { d'or cheese }\end{array}$ & Switzerland & 1985 & 215 cases & Anonymous (1986) \\
\hline Salmonella Dublin & $\begin{array}{l}\text { Soft stilton cheese from } \\
\text { unpasteurised milk }\end{array}$ & England and Wales & 1989 & 42 cases & Maguire et al. (1992) \\
\hline Salmonella Paratyphi B & Raw goat milk cheese & France & 1990 & 277 cases & $\begin{array}{l}\text { Grimont and Bouvet } \\
\text { (1991) }\end{array}$ \\
\hline Salmonella Paratyphi B & Raw goat milk cheese & France & 1993 & 273 cases, 1 dead & Desenclos et al. (1996) \\
\hline Salmonella Berta & $\begin{array}{l}\text { Farm soft cheese from } \\
\text { unpasteurised milk }\end{array}$ & Canada & 1994 & 35 confirmed cases & Ellis et al. (1998) \\
\hline Salmonella Dublin & $\begin{array}{l}\text { Raw cow milk mont d'or } \\
\text { cheese }\end{array}$ & $\begin{array}{l}\text { France and } \\
\text { Switzerland }\end{array}$ & 1995 & $\begin{array}{l}25 \text { cases, } 12 \text { hospitalised, } 5 \\
\text { dead }\end{array}$ & Vaillant et al. (1996) \\
\hline Salmonella Dublin & $\begin{array}{l}\text { Raw cow milk mont d'or } \\
\text { cheese }\end{array}$ & France & 1996 & 14 cases, 1 dead & $\begin{array}{l}\text { Infuso, Vaillant, and } \\
\text { Desenclos (1997) }\end{array}$ \\
\hline $\begin{array}{l}\text { Salmonella Typhimurium } \\
\text { PT12 atypical }\end{array}$ & Raw milk morbier cheese & France & 1997 & 113 cases & De Valk et al. (2000) \\
\hline $\begin{array}{l}\text { Salmonella Typhimurium } \\
\text { var Copenhagen phage } \\
\text { type DT104 (outbreak 1) } \\
\text { and non-var Copenhagen } \\
\text { phage type DT 104b } \\
\text { (outbreak 2) }\end{array}$ & $\begin{array}{l}\text { Unpasteurised Mexican- } \\
\text { style cheese }\end{array}$ & United States & 1997 & $\begin{array}{l}31 \text { confirmed cases } \\
\text { (outbreak 1); } 79 \text { cases } \\
\text { (outbreak 2) }\end{array}$ & Cody et al. (1999) \\
\hline Salmonella Typhimurium DT104 & $\begin{array}{l}\text { Unpasteurised Mexican- } \\
\text { style cheese }\end{array}$ & United States & 1997 & 54 confirmed cases & Villar et al. (1999) \\
\hline Salmonella Newport & Raw milk cheese & United States & 2001 & 27 cases, 12 hospitalised & CDC (2014) \\
\hline Salmonella Enteritidis phage type 8 & Raw milk cantal cheese & France & 2001 & 215 cases & $\begin{array}{l}\text { Haeghebaert et al. } \\
\text { (2003) }\end{array}$ \\
\hline Salmonella Typhimurium & $\begin{array}{l}\text { Unpasteurised queso-fresco } \\
\text { cheese }\end{array}$ & United States & 2003 & 50 cases, 7 hospitalised & CDC (2014) \\
\hline Salmonella Typhimurium & $\begin{array}{l}\text { Unpasteurised queso-fresco } \\
\text { cheese }\end{array}$ & United States & 2004 & $\begin{array}{l}12 \text { cases, } 1 \text { hospitalised and } \\
1 \text { dead }\end{array}$ & CDC (2014) \\
\hline Salmonella & $\begin{array}{l}\text { Unpasteurised queso-fresco } \\
\text { cheese }\end{array}$ & United States & 2005 & 2 cases & CDC (2014) \\
\hline Salmonella Typhimurium & $\begin{array}{l}\text { Unpasteurised queso-fresco } \\
\text { cheese }\end{array}$ & United States & 2006 & 20 cases, 2 hospitalised & CDC (2014) \\
\hline Salmonella enterica Newport & $\begin{array}{l}\text { Unpasteurised Mexican- } \\
\text { style aged cheese }\end{array}$ & United States & $2006-2007$ & $\begin{array}{l}85 \text { cases (but no significant } \\
\text { association) }\end{array}$ & CDC (2008) \\
\hline Salmonella Typhimurium & $\begin{array}{l}\text { Raw milk cheese and raw } \\
\text { milk }\end{array}$ & United States & 2007 & 29 cases & CDC (2007) \\
\hline Salmonella enteric Muenster & Unpasteurised goat cheese & France & 2008 & $\begin{array}{l}25 \text { laboratory-confirmed } \\
\text { cases, } 4 \text { hospitalised }\end{array}$ & $\begin{array}{l}\text { van Cauteren et al. } \\
\text { (2009) }\end{array}$ \\
\hline Escherichia coli 0119:B14 (vtx2) & $\begin{array}{l}\text { Farm fresh cheese from raw } \\
\text { cow and goat milk }\end{array}$ & France & $1992-1993$ & 4 cases, 4 HUS, 1 dead & Casenave et al. (1993) \\
\hline E. coli $\mathrm{O} 157(\mathrm{PT} 28, v t \times 2)$ & Farm raw milk cheese & Scotland & 1994 & 22 cases, 1 HUS & Ammon (1997) \\
\hline E. coli 0103 & $\begin{array}{l}\text { Farm fresh cheese from raw } \\
\text { goat milk }\end{array}$ & France & 1994 & 4 cases, 4 HUS & Decludt (1995) \\
\hline E. coli $0110: \mathrm{H}_{-}$ & Raw milk cheese & Germany & 1996 & 3 cases, 0 HUS & $\begin{array}{l}\text { Bockemühl and Karch } \\
\text { (1996) }\end{array}$ \\
\hline E. coli $0157: \mathrm{H7}$ & Fresh cheddar cheese curds & United States & 1998 & $\begin{array}{l}63 \text { cases, } 55 \text { laboratory- } \\
\text { confirmed, } 24 \text { hospitalised }\end{array}$ & CDC (2000) \\
\hline E. coli $0157: \mathrm{H7}$ & Unpasteurised cream & England & 1998 & 7 cases & CDSC (1998a) \\
\hline E. coli $0157(\mathrm{PT} 2, v t \times 2)$ & $\begin{array}{l}\text { Cheese from unpasteurised } \\
\text { milk }\end{array}$ & England & 1998 & 10 cases, 1 HUS case & CDSC (1998b) \\
\hline E. coli 0157 & Unpasteurised farm cheese & Scotland & 1998 & 4 cases & Strachan et al. (2006) \\
\hline E. coli 0157 (PT21, PT28) & $\begin{array}{l}\text { Homemade raw goat milk } \\
\text { cheese }\end{array}$ & Scotland & 1999 & 27 cases, 1 HUS & Curnow (1999) \\
\hline E. coli $0157: \mathrm{H7}$ & $\begin{array}{l}\text { Unpasteurised gouda hard } \\
\text { cheese }\end{array}$ & Canada & $2002-2003$ & 13 cases, 2 HUS & Honish et al. (2005) \\
\hline E. coli $\mathrm{O} 157: \mathrm{H7}$ & $\begin{array}{l}\text { Unpasteurised queso-fresco } \\
\text { cheese }\end{array}$ & United States & 2004 & 3 cases, 2 hospitalised & CDC (2014) \\
\hline E. coli $0157: \mathrm{H} 7$ & Raw milk cheese & Canada & 2004 & 3 cases & MAPAQ (2004) \\
\hline E. coli 0157 (vtx2, eae) & $\begin{array}{l}\text { Farm fresh unpasteurised } \\
\text { goat cheese }\end{array}$ & France & 2004 & 3 cases, 2 HUS & Espié et al. (2006) \\
\hline E. coli $\mathrm{O} 26, \mathrm{O} 80$ (vtx2, eae $)$ & Raw milk brie & France & 2005 & 6 HUS & INVS (2007) \\
\hline E. coli $0157: \mathrm{H7}$ & Raw milk cheese & Canada & $2008-2009$ & 16 cases & Gaulin et al. (2012) \\
\hline E. coli $0157: \mathrm{H7}$ & $\begin{array}{l}\text { Aged raw milk gouda } \\
\text { cheese }\end{array}$ & United States & 2010 & 38 cases, 15 hospitalised & McCollum et al. (2012) \\
\hline
\end{tabular}


Table 2 (continued)

\begin{tabular}{|c|c|c|c|c|c|}
\hline Pathogenic agent & $\begin{array}{l}\text { Dairy product made from } \\
\text { raw milk }\end{array}$ & Country & Year & Cases & References \\
\hline E. coli $0157: \mathrm{H7}$, E. coli $0157: \mathrm{NM}(\mathrm{H}-)$ & Unpasteurised cheeses & United States & 2010 & 15 cases & CDC (2014) \\
\hline $\begin{array}{l}\text { E. coli } \mathrm{O} 157: \mathrm{H7} \text { and } \\
\quad \text { Listeria monocytogenes }\end{array}$ & $\begin{array}{l}\text { Unpasteurised gouda } \\
\text { cheese }\end{array}$ & United States & 2010 & $\begin{array}{l}38 \text { cases, } 15 \text { hospitalised, } 1 \\
\text { HUS }\end{array}$ & CDC (2014) \\
\hline Listeria & $\begin{array}{l}\text { Vacherin mont d'or cheese } \\
\text { from unpasteurised milk }\end{array}$ & Switzerland & 1983-1987 & 122 cases, 33 dead & Bille (1989) \\
\hline Listeria meningitis & $\begin{array}{l}\text { Anari raw goat milk soft } \\
\text { cheese }\end{array}$ & England & 1988 & 1 case & $\begin{array}{l}\text { Azadian, Finnerty, and } \\
\text { Pearson (1989) }\end{array}$ \\
\hline Listeria monocytogenes Serovar 4b & $\begin{array}{l}\text { Raw milk brie de meauw } \\
\text { cheese }\end{array}$ & France & 1995 & $\begin{array}{l}36 \text { cases, } 4 \text { dead, } 7 \text { foetal/ } \\
\text { neonatal cases }\end{array}$ & $\begin{array}{l}\text { Vaillant, Maillot, } \\
\text { Charley, and Stainer } \\
\text { (1998) }\end{array}$ \\
\hline Listeria monocytogenes Serovar 4b & $\begin{array}{l}\text { Raw milk livarot, pont- } \\
\text { l'évêque cheese }\end{array}$ & France & 1997 & 14 cases & $\begin{array}{l}\text { Jacquet, Saint-Cloment, } \\
\text { Brouille, Catimel, and } \\
\text { Rocourt (1998) }\end{array}$ \\
\hline Listeria monocytogenes & $\begin{array}{l}\text { Fresh Mexican-style raw } \\
\text { milk cheese }\end{array}$ & United States & 2000-2001 & $\begin{array}{l}13 \text { cases, } 11 \text { pregnant } \\
\text { women ( } 5 \text { stillbirths, } 3 \\
\text { premature deliveries, } 3 \\
\text { infected newborns) }\end{array}$ & $\begin{array}{l}\text { CDC (2001); } \\
\text { MacDonald et al. (2005) }\end{array}$ \\
\hline Listeria monocytogenes & $\begin{array}{l}\text { Unpasteurised queso-fresco } \\
\text { cheese }\end{array}$ & United States & 2003 & $\begin{array}{l}12 \text { cases, } 12 \text { hospitalised, } 1 \\
\text { dead }\end{array}$ & CDC (2014) \\
\hline Listeria monocytogenes & $\begin{array}{l}\text { Unpasteurised queso-fresco } \\
\text { cheese }\end{array}$ & United States & 2005 & $\begin{array}{l}12 \text { cases, } 12 \text { hospitalised, } \\
0 \text { dead }\end{array}$ & CDC (2014) \\
\hline Brucella melitensis & $\begin{array}{l}\text { Home-made fresh cottage } \\
\text { cheese from unpasteurised } \\
\text { milk }\end{array}$ & Spain & 1996 & 81 cases & $\begin{array}{l}\text { Castell Monsalve, } \\
\text { Rullán, and CallizoNiet- } \\
\text { Sandoval Alcolea } \\
\text { (1996) }\end{array}$ \\
\hline Brucella & $\begin{array}{l}\text { Homemade unpasteurised } \\
\text { cheese }\end{array}$ & United States & 2001 & 4 cases, 0 dead & CDC (2014) \\
\hline Brucella melitensis serovar 3 & $\begin{array}{l}\text { Unpasteurised raw goat } \\
\text { milk cheese }\end{array}$ & Spain & 2002 & 11 brucellosis cases & $\begin{array}{l}\text { Méndez Martínez et al. } \\
\text { (2003) }\end{array}$ \\
\hline Brucella & $\begin{array}{l}\text { Unpasteurised queso-fresco } \\
\text { cheese }\end{array}$ & United States & 2005 & $\begin{array}{l}2 \text { cases, } 2 \text { hospitalised, } \\
0 \text { dead }\end{array}$ & CDC (2014) \\
\hline Brucella & Unpasteurised goat cheese & United States & 2006 & $\begin{array}{l}5 \text { cases, } 3 \text { hospitalised, } \\
0 \text { dead }\end{array}$ & CDC (2014) \\
\hline Brucella & $\begin{array}{l}\text { Unpasteurised queso-fresco } \\
\text { cheese }\end{array}$ & United States & 2007 & $\begin{array}{l}3 \text { cases, } 1 \text { hospitalised, } \\
0 \text { dead }\end{array}$ & CDC (2014) \\
\hline Brucella abortus & Raw milk cheese & France & 2012 & 1 case $($ child) & $\begin{array}{l}\text { Bronner, Hénaux, } \\
\text { Fortané, Hendrikx, and } \\
\text { Calavas (2014) }\end{array}$ \\
\hline Campylobacter jejuni & $\begin{array}{l}\text { Homemade unpasteurised } \\
\text { cheese }\end{array}$ & United States & 2000 & $\begin{array}{l}18 \text { cases, } 0 \text { hospitalised, } \\
0 \text { dead }\end{array}$ & CDC (2014) \\
\hline Campylobacter jejuni & Unpasteurised cheese & United States & 2003 & $\begin{array}{l}18 \text { cases, } 0 \text { hospitalised, } \\
0 \text { dead }\end{array}$ & CDC (2014) \\
\hline Campylobacter jejuni & $\begin{array}{l}\text { Homemade unpasteurised } \\
\text { cheese }\end{array}$ & United States & 2006 & $\begin{array}{l}58 \text { cases, } 2 \text { hospitalised, } \\
0 \text { dead }\end{array}$ & CDC (2014) \\
\hline Campylobacter jejuni & Fresh raw milk cheese & United States & 2007 & 68 cases & CDC (2009) \\
\hline Campylobacter jejuni & $\begin{array}{l}\text { Unpasteurised queso-fresco } \\
\text { cheese }\end{array}$ & United States & 2009 & $\begin{array}{l}10 \text { cases, } 0 \text { hospitalised, } \\
0 \text { dead }\end{array}$ & CDC (2014) \\
\hline $\begin{array}{l}\text { Staphylococcus aureus } \\
\text { enterotoxins A and D }\end{array}$ & $\begin{array}{l}\text { Farm raw sheep milk } \\
\text { cheese }\end{array}$ & France & 1983 & 20 cases & $\begin{array}{l}\text { De Buyser, Janin, and } \\
\text { Dilasser (1985) }\end{array}$ \\
\hline Staphylococcus aureus enterotoxins A & Raw sheep milk cheese & Scotland & 1984 & 27 cases & $\begin{array}{l}\text { Bone, Bogie, and } \\
\text { Morgan-Jone (1989) }\end{array}$ \\
\hline Staphylococcus aureus & $\begin{array}{l}\text { Stilton cheese from } \\
\text { unpasteurised milk }\end{array}$ & England & 1988 & 155 cases & Maguire et al. (1991) \\
\hline Staphylococcal enterotoxin type E & $\begin{array}{l}\text { Soft cheese from } \\
\text { unpasteurised milk }\end{array}$ & France & 2009 & 6 outbreaks, 23 cases & Ostyn et al. (2010) \\
\hline $\begin{array}{l}\text { Streptococcus equi, } \\
\text { Streptococcus zooepidemicus } \\
\quad \text { (group C) }\end{array}$ & $\begin{array}{l}\text { Mexican-style soft raw milk } \\
\text { cheese (queso fresco) }\end{array}$ & United States & 1983 & $\begin{array}{l}16 \text { cases, } 5 \text { hospitalised, } 3 \\
\text { dead }\end{array}$ & $\begin{array}{l}\text { Altekruse et al. (1998); } \\
\text { CDC (1983) }\end{array}$ \\
\hline Tick-borne encephalitis virus & $\begin{array}{l}\text { Cheese from raw cow and } \\
\text { goat milk }\end{array}$ & Austria & 2008 & 6 cases & Holzmann et al. (2009) \\
\hline
\end{tabular}

consumption of dairy products made from raw milk and in 2013 one outbreak was reported due to VTEC 0157 contamination of unpasteurised cheese (EFSA \& ECDC, 2015).

The majority of the outbreaks (22 out of 64) due to the consumption of raw milk cheeses was caused by Salmonella, followed by VTEC. Consumption of contaminated soft and semi-soft cheeses is often implicated in outbreaks with VTEC, especially when they are made of unpasteurised cow or goat milk. VTEC 0157:H7 is linked to the majority of the VTEC outbreaks, but also other serotypes have been implicated (Farrokh et al., 2013). C. jejuni (in the United States), L. monocytogenes and Brucella spp. were relatively often linked to raw milk cheese outbreaks, respectively 5, 8 and 7 out of 64 outbreaks. Dairy products made from raw milk can be a transmission route of Brucella spp. (EFSA \& ECDC, 2014). In Mediterranean countries not officially free from brucellosis, it is assumed that the consumption of raw sheep and goat milk as well 
as cheese made from raw sheep and goat milk is the main source of contamination (FASFC, WIV, \& CODA, 2011). Magwedere et al. (2011) have shown that raw goat milk, home-made goat cheese and coffee served with raw goat milk, as well as contact with goats can be a source of human cases of brucellosis. Enterotoxinproducing S. aureus, Streptococcus spp. and the TBEV were also linked to the consumption of raw milk cheeses. Three of the four outbreaks of $S$. aureus occurred more than 20 years ago, and two were caused by cheese made from raw sheep milk. Concerning Streptococcus, one outbreak occurred in the United States due to Mexican-style soft raw milk cheese in 1983. In 1997-2008, 64 cases of tick-borne encephalitis in patients that consumed unpasteurised milk and cheese made from sheep milk were reported in the Czech Republic (Kř̌iž, Beneš, \& Daniel, 2009).

\section{Growth and survival of pathogenic microorganisms during production and storage/ripening of dairy products made from raw milk}

The circumstances of production and storage of dairy products made from raw milk determine the behaviour (i.e., growth, survival or inactivation) of the microorganisms that are potentially present in the raw milk. The pathogens can grow, survive or be inactivated. Some of these important influencing factors are summarised as follows for raw milk cheeses. The growth of the fermenting bacteria reduces the growth possibilities of the pathogens by, on the one hand, competition and, on the other hand, a decline of the $\mathrm{pH}$. The effect of starter cultures producing bacteriocins and the addition of potassium or sodium nitrate is especially aimed at inhibiting the growth of butyric acid bacteria. The outgrowth of L. monocytogenes could also be influenced due to the presence of bacteriocins (Dal Bello et al., 2012) while the outgrowth of B. cereus may be ascribed to potassium or sodium nitrate inhibiting spore germination (Avila, Gómez-Torres, Hernández, \& Garde, 2014). The coagulation of the milk followed by sineresis of the curd, concentrates the pathogens in the curd. Some herbs used in the cheeses may have a bacteriostatic effect (Leuschner \& Ielsch, 2003).

Salting creates conditions that are not optimal for survival or growth due to the decline of the water activity. Depending on the time, temperature, $\mathrm{pH}$, water activity and $\mathrm{NaCl}$ concentration, dry matter content and the competing microbiota, growth or inactivation of the pathogens present in the milk will occur during ripening (Farrokh et al., 2013). Plastic coating used on certain cheeses prevents them from drying out and prevents contamination with pathogens and fungi from the environment. The coating may contain antifungal components such as natamycin. Vacuum packaging and paraffin are physical barriers and the vacuum packaging will inhibit the development of fungi and strict aerobic microorganisms. The presence of internal and external microbiota during ripening provides competition with the pathogens. During the ripening period, the physical and chemical characteristics of the cheese often change which can provide a better survival and even enable growth. During ripening a post-contamination can occur. Especially soft and semi-soft cheeses as well as cheeses with a washed crust such as red smear cheeses, are more exposed to surface contamination (Farrokh et al., 2013). Microorganisms will behave differently on the surface or in the crust due to the different conditions such as the $\mathrm{pH}$.

The results documented in specific studies on the survival, growth and inactivation of pathogens in dairy products made from raw milk are summarised in Table 3. Information was only available for cheeses and butter. Concerning cheese, a distinction was made between hard, semi-hard and soft cheeses based on the classification made in the publications. When this classification was not clear, 'non specified' cheeses are mentioned.
It can be concluded from Table 3 that during the production of hard cheeses, some bacteria can survive, such as Salmonella, L. monocytogenes, S. aureus and MAP, albeit without subsequent growth. The number of E. coli can increase during the cheese production, which is due to a combination of a concentration effect during the formation of the curd as well as due to real growth of the pathogen (Farrokh et al., 2013). In hard cheeses several pathogens can be inactivated during storage. Salmonella, E. coli, L. monocytogenes and MAP may decrease in numbers, but can still be detected after long ripening periods. During the production of semi-hard cheeses, some bacteria can grow, such as Salmonella, E. coli and S. aureus. L. monocytogenes and MAP that survive the production process. During the ripening and storage of semi-hard cheeses, most bacteria will decrease in numbers, but Salmonella, E. coli and S. aureus can still be detected. L. monocytogenes and MAP can survive the ripening and storage. During the production of soft cheeses, E. coli, L. monocytogenes and Brucella spp. can grow. During the ripening and storage, E. coli and Brucella spp. can survive, but L. monocytogenes can possibly grow in and on soft cheeses, depending on the ripening stage and the circumstances. The growth of L. monocytogenes in butter does not occur or is limited (De Reu \& Herman, 2004).

\section{Identification of main microbiological hazards in dairy products made from raw milk}

The information on the possible presence of human pathogenic microorganisms in raw milk, frequencies of occurrence of human pathogenic microorganisms in dairy products made from raw milk in Europe, outbreaks resulting from consumption of dairy products made from raw milk in Europe, the United States and Canada and the worst case scenario of the behaviour in dairy products made from raw milk is summarised in Table 4.

The main microbiological hazards linked to raw milk cheese are L. monocytogenes, human pathogenic VTEC, Salmonella, enterotoxin-producing S. aureus and Campylobacter. These pathogens can be present in raw milk and as there is no heat treatment before cheese production, they will not be inactivated. They have all caused a certain number of outbreaks linked to cheese and Salmonella, L. monocytogenes, S. aureus and VTEC have been detected in cheeses. Salmonella, Campylobacter and VTEC can cause disease in low numbers (often a few cells) and for Salmonella and VTEC there are growth possibilities during production and storage (survival for VTEC during storage). L. monocytogenes and S. aureus have to grow to cause disease, which is possible as can be seen from Table 4.

Concerning butter, cream and buttermilk, there is less information available in the scientific literature. For butter made from raw milk, the main microbiological hazards are $L$. monocytogenes, VTEC and $S$. aureus because these pathogens have been detected in butter. However, the risk of infection after consumption of raw milk butter is estimated to be relatively lower in comparison with certain cheeses, especially due to the limited growth possibilities of L. monocytogenes. For cream made from raw milk, the main microbiological hazards are estimated to be L. monocytogenes, $S$. aureus and VTEC because $L$. monocytogenes and $S$. aureus have been detected in cream and VTEC was linked to a cream outbreak. With regard to buttermilk made from raw milk, there is no information available in the scientific literature and the microbiological hazards related to the consumption of this product cannot be identified.

There are some additional risks linked to the consumption of dairy products made from raw milk, especially when they are produced on farms where animals are frequently infected with certain pathogens. This is the case for Brucella spp. Cattle can be 
Table 3

Behaviour of human pathogenic microorganisms in different types of cheese made from raw milk during production and storage/ripening.

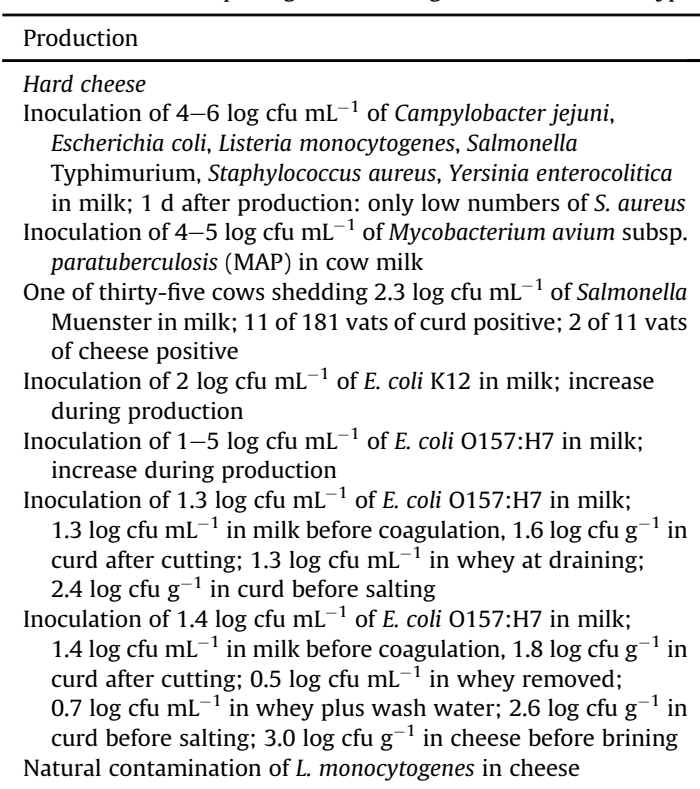

Semi-hard cheese

Inoculation of $4-6 \log \mathrm{cfu} \mathrm{mL}^{-1}$ of $C$. jejuni, E. coli,

L. monocytogenes, S. Typhimurium, S. aureus, Y. enterocolitica in milk

Inoculation of $4-5 \log \mathrm{cfu} \mathrm{mL}^{-1}$ of MAP in cow milk

Inoculation of 1 and $3 \log \mathrm{cfu} \mathrm{mL}^{-1}$ of $E$. coli ( 5 strains including 3 verocytotoxin-producing Escherichia coli (VTEC))

Inoculation of $2.4 \log \mathrm{cfu} \mathrm{mL} \mathrm{L}^{-1}$ S. aureus in milk; $3.3 \log \mathrm{cfu} \mathrm{mL} \mathrm{L}^{-1}$ in gel of early coagulation; $2.3 \log$ cfu $\mathrm{mL}^{-1}$ in whey. $4.2 \log$ cfu $\mathrm{g}^{-1}$ in curd at pressing

Inoculation of $4 \log \mathrm{cfu}^{-1}$ of $L$. monocytogenes in sheep milk

\section{Soft cheese}

Inoculation of $4 \log \mathrm{cfu} \mathrm{mL}^{-1}$ of $E$. coli $0157: \mathrm{H} 7$ and L. monocytogenes; growth of both pathogens during production

Inoculation of $4 \log \mathrm{cfu} \mathrm{mL}^{-1}$ of $E$. coli $0157: \mathrm{H} 7$ and L. monocytogenes; growth of both pathogens during production

Inoculation of $3 \log \mathrm{cfu} \mathrm{mL}^{-1}$ of VTEC; increase of 1 $-2 \log \mathrm{cfu} \mathrm{g}^{-1}$ during production; stabilisation during salting/drying

Inoculation of $3.6 \mathrm{log} \mathrm{cfu} \mathrm{mL} \mathrm{L}^{-1}$ of Brucella abortus in milk; $4.2 \log$ cfu g ${ }^{-1}$ in curd; $4.3 \log \mathrm{cfu} \mathrm{g}^{-1}$ in curd out of mould

Inoculation of -0.7 and $0.3 \log \mathrm{cfu}^{-2}$ of L. monocytogenes

Natural contamination of $3.8 \log \mathrm{cfu} \mathrm{mL}^{-1}$ of L. monocytogenes in sheep milk

\section{Mozzarella}

Inoculation of $5 \log$ cfu $\mathrm{mL}^{-1}$ of $E$. coli $0157: \mathrm{H} 7$ in cow milk; curd stretching at $80{ }^{\circ} \mathrm{C}$ for $5 \mathrm{~min}$ : loss of viability; curd stretching at $70{ }^{\circ} \mathrm{C}$ for $5 \mathrm{~min}$ : 1 log reduction

Inoculation of 7.1-8.7 $\log \mathrm{cfu}^{-1}$ of VTEC 0157 and 026 of curd; $4 \mathrm{D}$ reduction during heating curd

Storage and/or ripening

One week after storage at $11-13^{\circ} \mathrm{C}$ for $90 \mathrm{~d}$ : no detection of any of inoculated pathogens

Steady and slow decrease during ripening at $12{ }^{\circ} \mathrm{C}$ for $10 \mathrm{~d}, 22^{\circ} \mathrm{C}$ for $60 \mathrm{~d}$ or $12{ }^{\circ} \mathrm{C}$ for $50 \mathrm{~d}$; viable cells detected at day 120

One of two vats positive after storage at $5{ }^{\circ} \mathrm{C}$ for $125 \mathrm{~d}$

\section{Decrease of $1.5-2$ log during storage at $4{ }^{\circ} \mathrm{C}$ for $120 \mathrm{~d}$}

Storage at $7{ }^{\circ} \mathrm{C}$ for $1 \mathrm{wk}$; decrease of less than $1 \log \mathrm{cfu} \mathrm{g}^{-1}$ at day 60 ; decrease of less than $2 \log \mathrm{cfu} \mathrm{g}^{-1}$ at day 120

Storage at $9{ }^{\circ} \mathrm{C} ; 2.2 \log \mathrm{cfu} \mathrm{mL}^{-1}$ in cheese on day 1 ; decrease to

$1.4 \log$ cfu g $\mathrm{g}^{-1}$ on day 60 ; below $0.7 \log$ cfu g $^{-1}$ after $108 \mathrm{~d}$;

Detection after more than $270 \mathrm{~d}$

Storage at $14{ }^{\circ} \mathrm{C}$ for $5 \mathrm{wk}$, then at $9{ }^{\circ} \mathrm{C} ; 2.2 \log \mathrm{cfu} \mathrm{mL} \mathrm{L}^{-1}$ in cheese on day 1 ; decrease to $0.7 \log$ cfu g $\mathrm{g}^{-1}$ on day 60 ; below $0.7 \log \mathrm{cfu} \mathrm{g}^{-1}$ after $94 \mathrm{~d}$; detection after more than $270 \mathrm{~d}$

Never $>1.3 \log$ cfu $^{-1}$; no detection after 5 months

After storage at $11-13{ }^{\circ} \mathrm{C}$ for $90 \mathrm{~d}$ : only L. monocytogenes detected

Steady and slow decrease during ripening at $14-15{ }^{\circ} \mathrm{C}$ for $120 \mathrm{~d}$; viable cells detected at day 120

Increase of $3.5 \log \mathrm{cfu} \mathrm{g}^{-1}$ at day 1 (concentration effect and growth); slow and continuous decrease during ripening; generic E. coli Survived at higher counts; 6 cheeses with low inoculum: $>1 \log \mathrm{cfu}^{-1}$ at end of ripening; after enrichment: VTEC detection in almost all cheeses

$3.8 \log \mathrm{cfu} \mathrm{g}^{-1}$ in cheese at day $7 ; 0 \mathrm{cfu} \mathrm{g}^{-1}$ in cheese at week 10

Decrease after $6 \mathrm{wk}$; log reduction at $4{ }^{\circ} \mathrm{C}: 2.10$ at day $91,3.19$ at day 101 , presence at day 111 , absent at day 114 ; log reduction at $12{ }^{\circ} \mathrm{C}$ : 1.74 at day $77,2.90$ at day 91 , presence at day 98 , absent at day 104 $\log$ reduction at $22{ }^{\circ} \mathrm{C}: 1.76$ at day $54,2.45$ at day $67,4.02$ at day 70 , presence at day 74 , absent at day 77

Storage at $2{ }^{\circ} \mathrm{C}$ for $75 \mathrm{~d}$; E. coli 0157:H7: highest count at day 10 , decrease after $10 \mathrm{~d}$, count at day 75 higher than inoculum; L. monocytogenes: survival, count at day 75 higher than inoculum Storage at $2{ }^{\circ} \mathrm{C}$ for $65 \mathrm{~d}$; E. coli 0157:H7: highest count after $24 \mathrm{~h}$, decrease after $24 \mathrm{~h}$, count at day 65 higher than inoculum; L. monocytogenes: survival, count at day 65 higher than inoculum Storage at $4{ }^{\circ} \mathrm{C}$; decrease during early stages of ripening

Storage at $12{ }^{\circ} \mathrm{C} ; 3.0 \log \mathrm{cfu} \mathrm{g}^{-1}$ in cheese at day $5,1.5 \log \mathrm{cfu} \mathrm{g}^{-1}$ in cheese at day $8,1.3 \log \mathrm{cfu} \mathrm{g}^{-1}$ in cheese at day $12,1.1 \log \mathrm{cfu} \mathrm{g}^{-1}$ in cheese at day 15, $0.4 \log \mathrm{cfu} \mathrm{g}^{-1}$ in cheese at day $18,0 \mathrm{cfu} \mathrm{g}^{-1}$ in cheese at day 22

Storage at $4{ }^{\circ} \mathrm{C}$; increase after day 28 ; increase to $2.96 \log \mathrm{cfu} \mathrm{g}^{-1}$ at day 60 (low inoculum); increase to $4.55 \log$ cfu g ${ }^{-1}$ at day 60 (high inoculum)

2.3-2.8 $\log$ cfu $\mathrm{g}^{-1} 7 \mathrm{~d}$ after storage at $4{ }^{\circ} \mathrm{C}$ for $7 \mathrm{~d}$

Storage at $4{ }^{\circ} \mathrm{C}$ for $7 \mathrm{~d}$; no detection

Trevisani, Mancusi, and

Valero (2014)

(continued on next page)
Bachmann and Spahr (1995)

Spahr and Schafroth (2001)

Wood, Collins-Thompson, Irvine, and Muhr (1984)

Amornkul and Henning (2007)

Schlesser et al. (2006)

D'Amico, Druart, and Donnelly (2010)

D'Amico et al. (2010)

Dalmasso and Jordan (2014)

Bachmann and Spahr (1995)

Spahr and Schafroth (2001)

Peng et al. (2013)

Ramsaran, Chen, Brunke, Hill, and Griffiths (1998)

Ramsaran et al. (1998)

Montet et al. (2009)

Plommet et al. (1988)

Schoder, Winter, Kareem, Baumgartner, and Wagner (2003)

\section{Spano et al. (2003)}


Table 3 (continued)

\begin{tabular}{|c|c|c|}
\hline Production & Storage and/or ripening & References \\
\hline \multicolumn{3}{|l|}{ Non specified cheese } \\
\hline $\begin{array}{l}\text { Inoculation of } E \text {. coli } 0157: \mathrm{H} 7, \mathrm{O} 26: \mathrm{H} 11, \mathrm{O} 103: \mathrm{H} 2 \text { and } \\
\text { O145: } \mathrm{H} 28 \text { in cow, goat or sheep milk; during first } 24 \mathrm{~h} \text { of } \\
\text { production: growth of } 2-3 \log \mathrm{cfu}^{-1} \text {, no growth when acid } \\
\text { coagulation }\end{array}$ & $\begin{array}{l}\text { Decrease during } 6 \text { months of ripening; detectable at end of storage/ } \\
\text { ripening }\end{array}$ & Miszczycha et al. (2013) \\
\hline $\begin{array}{l}\text { Inoculation of } E \text {. coli } 0157: \mathrm{H} 7 \text { and } 026: \mathrm{H} 11 \text { in cow milk; during } \\
\text { first } 24 \mathrm{~h} \text { of production: growth from } 2 \text { to } 4 \log \mathrm{cfu}^{-1}\end{array}$ & Stable around $4 \log \mathrm{cfu} \mathrm{g}^{-1}$ during ripening and storage & Miszczycha et al. (2014) \\
\hline Inoculation of $1.52 \log \mathrm{cfu} \mathrm{mL}^{-1}$ of $E$. coli $0157: \mathrm{H} 7$ in milk & $\begin{array}{l}\text { Storage a } 6{ }^{\circ} \mathrm{C} \text {; increase to } 3.4 \log \mathrm{cfu}^{-1} \text { at day } 1 \text {; decrease during } \\
\text { ripening to }<0 \mathrm{cfu} \mathrm{g}^{-1} \text { in rind at day } 21 \text {; decrease during ripening to } \\
<1 \log \text { cfu } \mathrm{g}^{-1} \text { in core at day } 21 \text {; detection of viable cells at day } 90\end{array}$ & $\begin{array}{l}\text { Maher, Jordan, Upton, and } \\
\text { Coffey (2001) }\end{array}$ \\
\hline $\begin{array}{l}\text { Inoculation of } 3.56 \log \mathrm{cfu}^{-1} \text { dry weight of L. monocytogenes in } \\
\text { cow milk; no growth during production }\end{array}$ & $\begin{array}{l}\text { Storage at } 13^{\circ} \mathrm{C} \text { for } 14 \mathrm{~d} \text { and at } 8^{\circ} \mathrm{C} \text { for } 14 \mathrm{~d} \text {; increase of } 2 \log \mathrm{cfu} \mathrm{g}^{-1} \\
\text { dry weight during first } 4 \mathrm{~d} \text { of ripening; survival/decrease until end } \\
\text { of ripening }\end{array}$ & Schvartzman et al. (2011) \\
\hline $\begin{array}{l}\text { Inoculation of } 6 \log \text { cfu } \mathrm{mL}^{-1} \text { of } E \text {. coli, Listeria innocua and } \\
\text { S. aureus in milk; during production; increase of } E \text {. coli, } \\
\text { survival of L. innocua and S. aureus }\end{array}$ & $\begin{array}{l}\text { Storage at } 8{ }^{\circ} \mathrm{C} \text { for } 56 \mathrm{~d} \text {; E. coli highest count at day 7, decrease after } \\
\text { day 7; Listeria innocua and Staphylococcus aureus no growth }\end{array}$ & Masoud et al. (2012) \\
\hline $\begin{array}{l}\text { Average counts of } S . \text { aureus: } 1.26 \log \mathrm{cfu} \mathrm{mL}^{-1} \text { in cow/goat milk, } \\
2.80 \log \mathrm{cfu} \mathrm{mL} \mathrm{L}^{-1} \text { in curd }\end{array}$ & $\begin{array}{l}\text { Average counts of } S \text {. aureus: } 3.50 \mathrm{log} \mathrm{cfu} \mathrm{g}^{-1} \text { in cheese }(5-6 \mathrm{~h}) \text {, } \\
3.13 \log \mathrm{cfu} \mathrm{mL} \mathrm{mL}^{-1} \text { in cheese }(24 \mathrm{~h}), 1.04 \mathrm{log} \mathrm{cfu}^{-1} \text { in cheese }(30 \mathrm{~d})\end{array}$ & Jakobsen et al. (2011) \\
\hline $\begin{array}{l}\text { Inoculation of } 9.7 \log \text { cfu } \mathrm{g}^{-1} \text { of Brucella melitensis in goat milk; } \\
\text { decrease during production; } 6.3 \log \mathrm{cfu} \mathrm{mL}^{-1} \text { in whey at curd } \\
\text { cutting; } 6 \log \mathrm{cfu} \mathrm{mL}^{-1} \text { at draining }\end{array}$ & $\begin{array}{l}3.0 \log \mathrm{cfu} \mathrm{mL}^{-1} \text { during storage at } 4{ }^{\circ} \mathrm{C} \text { for } 13-30 \mathrm{~d} ; 4 \log \mathrm{cfu} \mathrm{mL}^{-1} \\
\text { during storage at } 24{ }^{\circ} \mathrm{C} \text { for } 6-15 \mathrm{~d} \text {; no detection during storage at } \\
24{ }^{\circ} \mathrm{C} \text { for days } 16-30\end{array}$ & $\begin{array}{l}\text { Méndez-González et al. } \\
\text { (2011) }\end{array}$ \\
\hline \multicolumn{3}{|l|}{ Butter } \\
\hline Inoculation of $L$. monocytogenes and $L$. innocua in cream & No significant growth during storage at 4,10 or $20^{\circ} \mathrm{C}$ for $4 \mathrm{wk}$ & De Reu and Herman (2004) \\
\hline $\begin{array}{l}\text { Natural contamination of }-0.6 \text { to } 1.2 \log \mathrm{cfu}^{-1} \text { of } \\
\text { L. monocytogenes }\end{array}$ & One log reduction during storage at 4 or $10^{\circ} \mathrm{C}$ for 4 or $5 \mathrm{wk}$ & De Reu and Herman (2004) \\
\hline
\end{tabular}

infected with Brucella abortus and sheep can be infected with Brucella melitensis in certain areas of Southern Europe. The same holds for $M$. bovis in regions where this pathogen is endemic, for example among cattle. Goats can be parasitised by the tick Ixodes ricinus that often carry the TBEV. The infection of goats is asymptomatic and the TBEV can enter the bloodstream through the tick followed by an excretion in the milk during the viraemic phase. In risk areas in Eastern Europe the TBEV can be endemic and therefore this is also an important microbiological hazard linked to dairy products made from raw milk.

For some microorganisms, the foodborne potential is not known or limited documentation is available. Cattle, goats and sheep are the main reservoirs of $C$. burnetii (Rahimi, Doosti, Ameri, Kabiri, \& Sharifian, 2008). In general, people get infected by inhalation of contaminated dust and aerosols mainly formed during birth of animals, via manure or via contact with infected animals (Sci Com, 2010a, 2010b). Infection via the food chain occurs less frequently (Berri et al., 2005). Infectious C. burnetii can persist for long periods in milk and milk products. From scientific literature, it appears that dairy products made from unpasteurised milk may contain viable C. burnetii. Concerning MAP, the information in the scientific literature is limited and up to now, there is uncertainty whether this bacterium is zoonotic or to be considered as a human foodborne pathogen. Nevertheless, MAP and C. burnetii could be considered as

Table 4

Summary of information on microbiological hazards.

\begin{tabular}{|c|c|c|c|c|c|c|}
\hline \multirow[t]{2}{*}{ Organism } & \multirow{2}{*}{$\begin{array}{l}\text { Possibly } \\
\text { present in } \\
\text { raw milk }\end{array}$} & \multirow{2}{*}{$\begin{array}{l}\text { Detected in dairy } \\
\text { products made from } \\
\text { raw milk (minimum } \\
\text { - maximum frequency } \\
\text { of occurrence in \%) } \\
\text { in Europe }\end{array}$} & \multirow{2}{*}{$\begin{array}{l}\text { Reported human } \\
\text { cases and outbreaks } \\
\text { in Europe, the } \\
\text { US and Canada due } \\
\text { to cheese consumption }\end{array}$} & \multicolumn{2}{|c|}{ Worst case behaviour in raw milk cheese } & \multirow{2}{*}{$\begin{array}{l}\text { Score according to } \\
\text { EFSA (2013) }\end{array}$} \\
\hline & & & & Production & Storage/ripening & \\
\hline Listeria monocytogenes & Yes & $\begin{array}{l}0.0-41.9 \text { (cheese, } \\
\text { butter, cream) }\end{array}$ & 8 & $\begin{array}{l}\text { Growth } \\
\text { survival }^{\mathrm{b}}\end{array}$ & $\begin{array}{l}\text { Growth } \\
\text { survival }^{\mathrm{b}}\end{array}$ & 2 \\
\hline $\begin{array}{l}\text { Escherichia coli (human } \\
\text { pathogenic) }\end{array}$ & Yes & $0.0-55.3$ (cheese) & $18^{\mathrm{a}}$ & Growth & Survival & 3 \\
\hline Staphylococcus aureus & Yes & $0.0-100.0$ (cheese, butter) & 4 & Growth & Growth & 1 \\
\hline Salmonella & Yes & $0.0-4.3$ (cheese) & 22 & Growth & Growth & 3 \\
\hline Campylobacter & Yes & 0.0 (cheese) & 5 & No survival & No survival & 3 \\
\hline Brucella & Yes & $--^{c}$ & 7 & Growth & Survival & 3 \\
\hline Bacillus cereus & Yes & $0.0-28.0$ (cheese) & 0 & - & - & 1 \\
\hline Mycobacterium bovis & Yes & - & 0 & - & - & 3 \\
\hline Tick-borne encephalitis virus & Yes & - & 1 & - & - & 3 \\
\hline Coxiella burnetii & Yes & 0.0-57.0 (cheese, cream) & 0 & - & - & $-{ }^{d}$ \\
\hline Streptococcus & Yes & - & 1 & - & - & $3^{e}$ \\
\hline $\begin{array}{l}\text { Mycobacterium avium subsp. } \\
\text { paratuberculosis }\end{array}$ & Yes & $0.0-20.0$ (cheese) & 0 & Survival & Survival & $-{ }^{\mathrm{f}}$ \\
\hline
\end{tabular}

a One due to cream consumption.

b In butter.

c A dash (-) indicates no information was available unless otherwise indicated.

d Foodborne potential not known.

e Pathogenic species not frequent

f Zoonotic potential not known. 
a potential microbiological hazard present in dairy products made from raw milk.

\section{Discussion}

The contamination levels of several pathogens such as L. monocytogenes and S. aureus usually encountered in raw milk are mostly lower than the level they have to reach to cause disease. It is assumed (based on the authors' expert opinion) that numbers of L. monocytogenes in raw cow milk are usually lower or at the level of ca. $1 \log \mathrm{cfu} \mathrm{mL}^{-1}$. In the case of a subclinical mastitis of the milk producing animal, high initial numbers of $L$. monocytogenes or S. aureus could be encountered in the raw milk (Pintado et al., 2009; Sahebekhtiari et al., 2011). Although this is rare and such milk is diluted in the normal industrial milk supply, it may occur, e.g., in a short supply chain. For low initial numbers of these pathogens that have to grow to produce disease, the growth possibilities during cheese production and storage will influence the risk of infection. When present in the raw milk, the growth of most pathogens is restricted by storage at refrigerator temperatures although, depending on the storage time and temperature, some pathogens such as $L$. monocytogenes could develop.

From the scientific literature, it seems that prevalences or concentrations of certain pathogens such as VTEC, L. monocytogenes, $S$. aureus and $C$. burnetii are mostly lower in dairy products made from pasteurised or heat treated milk than in dairy products made from raw milk (Civera et al., 2007; Eldin et al., 2013; Fach, Perelle, Dilasser, \& Grout, 2001; Greenwood, Roberts, \& Burden, 1991; Loncarevic, Danielsson-Tham, \& Tham, 1995; Rosengren, Fabricius, Guss, Sylvén, \& Lindqvist, 2010). Concerning outbreaks, it seems that cheese outbreaks are more linked to cheese made from unpasteurised milk than from cheese made from pasteurised milk (Altekruse, Timbo, Mowbray, Bean, \& Potter, 1998; De Buyser, Dufour, Maire, \& Lafarge, 2001; Gould, Mungai, \& Behravesh, 2014). Moreover, the study of Gould et al. (2014) showed that raw milk cheese outbreaks were mostly related to contamination of the raw product or the ingredients by pathogens from animals or the environment, whereas pasteurised cheese outbreaks were more related to health and hygiene of the workers in contact with the cheese.

Regarding the behaviour of the pathogens during production and storage of cheese, there are differences depending on the use of raw milk or pasteurised milk. For example, L. monocytogenes showed in an inoculation experiment growth during the cheese production process when made from pasteurised milk whereas no growth was observed when made from raw milk, most probably due to the presence of background flora. However, during cheese ripening, growth of this pathogen occurred in raw milk cheese, but inactivation occurred in pasteurised cheese due to the physicochemical conditions of the cheeses (Schvartzman et al., 2011). Another study found no difference in the growth potential of $L$. monocytogenes inoculated on the surface of cheeses made from raw or pasteurised milk during storage (D'Amico, Druart, \& Donnelly, 2008). In addition, the natural microbiota can influence the behaviour of pathogens in cheese. Delcenserie et al. (2014) found that cheese made from raw and pasteurised milk had different microbiota in the crust of the cheeses. Overall, pasteurisation ensures the inactivation of vegetative pathogenic microorganisms, which increases the safety of products made thereof in comparison with dairy products made from raw milk. However, it should be noted that dairy products made from pasteurised milk could be susceptible to post-contamination. Therefore, application of a good Hazard Analysis and Critical Control Points (HACCP) system during production is essential.
To limit the exposure to pathogens due to consumption of dairy products made from raw milk several control measures can be taken from farm to fork. At farm level, the pathogenic microorganisms that contaminate the raw milk can come from the milkproducing animal or from the environment. Mastitis or udder infection is the most common disease in cattle (Halasa, Huijps, Osteras, \& Hogeveen, 2007). The intramammary infection is mostly caused by bacteria that penetrate the udder through the teat canal. In the holistic approach of prevention and control of mastitis, it is of utmost importance to keep the infection pressure in the stable as low as possible by means of good hygiene management and optimal comfort of the cows to obtain a good udder health and optimal milk quality (Barkema et al., 1998; Elbers et al., 1998; van Gastelen, Westerlaan, Houwers, \& van Eerdenburg, 2011; Schukken, Grommers, Vandegeer, Erb, \& Brand, 1990). However, contamination of the milk during milking cannot completely be avoided, not even with elaborate cleaning and disinfection (Magnusson, Christiansson, Svensson, \& Kolstrup, 2006). Between the milking and the processing of dairy products, time should be restricted and temperatures kept as low as possible to prevent the pathogens that are possibly present from growing. During milk processing, a quick fermentation with efficient starter cultures should be applied to restrict the growth of the pathogens. After the production of cheese, a restriction of the shelf life and adherence to the cold chain from retail to consumer is important to ensure the safety of such products. The control of the procedures of cleaning and disinfection of the material that is used during the production process is also important from the milking to the sales of the products. Finally, both producers and consumers, in particular persons belonging to the YOPI group, should be aware of the risks pertaining to dairy products made from raw milk.

There are some limitations linked to the analysis of the information collected in this work. The frequencies of occurrence of pathogenic microorganisms in dairy products made from raw milk originate from ad hoc convenience sampling and the modalities conditions of the sampling plan (number of samples taken, method of analysis and corresponding limit of detection) as well as the method of analysis and detection limit may vary among these surveys and consequently it was not always easy to compare the outcome of these publications. Also, it is not known if the detected pathogens are able to cause disease. In particular, in the case of the detection of potential pathogenic E. coli serotypes, it is not known if all positive results actually refer to $E$. coli strains that carry virulence genes. Concerning the outbreaks due to the consumption of dairy products made from raw milk, only reported outbreaks were included. There can be underreporting due to, e.g., a long incubation period. Regarding the behaviour of the pathogens during the production process and the storage or ripening period of dairy products made from raw milk, it is evident that there is a variety of cheeses with their proper production process, intrinsic physicochemical characteristics, indigenous microbiota and actual storage conditions, which will impact on the growth potential of the pathogens.

\section{Conclusion}

Overall, the available information on some pathogens or dairy products made from raw milk is limited, but if everything is taken into consideration the microbiological hazards and dairy products made from raw milk of main concern are linked to raw milk cheeses and $L$. monocytogenes, pathogenic VTEC, enterotoxin-producing S. aureus, Salmonella and C. jejuni/coli. Next, L. monocytogenes, VTEC and $S$. aureus have been identified as microbiological hazards in raw milk butter and cream, albeit to a lesser extent because of a reduced growth potential of these pathogens in the latter products 
compared with cheese. In endemic areas, dairy products made from raw milk may also be contaminated with Brucella spp., M. bovis or the tick-borne encephalitis virus and need particular attention in monitoring and surveillance. Finally, C. burnetii and MAP are identified as potential hazards. For $C$. burnetii the role of food (dairy products made from raw milk) seems to be limited and for MAP no sufficient knowledge is available.

Due to the possible exposure of the consumer to the above mentioned pathogenic microorganisms in dairy products made from raw milk, appropriate risk communication on the consumption of these products in particular to a vulnerable population, is recommended.

\section{Acknowledgements}

The authors wish to thank the Scientific Committee of the Belgian Federal Agency for the Safety of the Food Chain (FASFC) for their scientific support.

\section{References}

Almeida, G., Figueiredo, A., Rôla, M., Barros, R. M., Gibbs, P., Hogg, T., et al. (2007). Microbiological characterization of randomly selected Portuguese raw milk cheeses with reference to food safety. Journal of Food Protection, 70, 1710-1716. Altekruse, S. F., Timbo, B. B., Mowbray, J. C., Bean, N. H., \& Potter, M. E. (1998). Cheese-associated outbreaks of human illness in the United States, 1973 to 1992: sanitary manufacturing practices protect consumers. Journal of Food Protection, 61, 1405-1407.

Ammon, A. (1997). Surveillance of enterohaemorrhagic E. coli (EHEC) infections and haemolytic uraemic syndrome (HUS) in Europe. Eurosurveillance, 2, 91-95.

Amornkul, Y., \& Henning, D. R. (2007). Utilization of microfiltration or lactoperoxidase system or both for manufacture of Cheddar cheese from raw milk. Journal of Dairy Science, 90, 4988-5000.

Anonymous. (1986). Epidémie de salmonellose due à un formage à pâte molle. Bulletin de l'Office Fédéral de la Santé Publique, 8, 48-49.

Arrese, E., \& Arroyo-Izaga, M. (2012). Prevalence of Listeria monocytogenes in Idiazabal cheese. Nutrición Hospitalaria, 27, 2139-2141.

Auvray, F., Lecureuil, C., Dilasser, F., Taché, J., \& Derzelle, S. (2009). Development of a real-time PCR assay with an internal amplification control for the screening of Shiga toxin-producing Escherichia coli in food. Letters in Applied Microbiology, $48,554-559$.

Avila, M., Gómez-Torres, N., Hernández, M., \& Garde, S. (2014). Inhibitory activity of reuterin, nisin, lysozyme and nitrate against vegetative cells and spores of dairy-related Clostridium species. International Journal of Food Microbiology, 172, 70-75.

Azadian, B. S., Finnerty, G. T., \& Pearson, A. D. (1989). Cheese-borne Listeria meningitis in immunocompetent patient. Lancet, 333, 322-323.

Bachmann, H. P., \& Spahr, U. (1995). The fate of potentially pathogenic bacteria in Swiss hard and semihard cheeses made from raw milk. Journal of Dairy Science, 78, 476-483.

Barkema, H. W., Schukken, Y. H., Lam, T. J. G. M., Beiboer, M. L., Benedictus, G., \& Brand, A. (1998). Management practices associated with low, medium, and high somatic cell counts in bulk milk. Journal of Dairy Science, 81, 1917-1927.

Berri, M., Rousset, E., Hechard, C., Champion, J. L., Dufour, P., Russo, P., et al. (2005). Progression of Q fever and Coxiella burnetii shedding in milk after an outbreak of enzootic abortion in a goat herd. Veterinary Record, 156, 548-549.

Bille, J. (1989). Anatomy of a foodborne listeriosis outbreak. In Proceedings of symposium on foodborne listeriosis, 7 September 1988, Wiesbaden, FRG (pp. 29-36). Hamburg, Germany: Behr's Verlag.

Bockemühl, J., \& Karch, H. (1996). Zur aktuellen Bedeutung der enterohämorrhagischen. Escherichia coli (EHEC) in Deutschland (1994-1995). Bundesgesundheitsblatt, 39, 290-296.

Bone, F. J., Bogie, D., \& Morgan-Jone, S. C. (1989). Staphylococcal food poisoning from sheep milk cheese. Epidemiology and Infection, 103, 449-458.

Bronner, A., Hénaux, V., Fortané, N., Hendrikx, P., \& Calavas, D. (2014). Why do farmers and veterinarians not report all bovine abortions, as requested by the clinical brucellosis surveillance system in France? BMC Veterinary Research, 10, 93.

Caro, I., \& García-Armesto, M. R. (2007). Occurrence of Shiga toxin-producing Escherichia coli in a Spanish raw ewe's milk cheese. International Journal of Food Microbiology, 116, 410-413.

Casenave, C., Desenclos, J. C., Maillot, E., Benoit, S., Deschenes, G., Nivet, H., et al. (1993). Elosions de syndrome hémolytique et urémique dans une commune rurale du Cher. Bulletin Epidémiologique Hebdomadaire, 48, 222-224.

Castell Monsalve, J., Rullán, J. V., Peiró Callizo, E. F., \& Niet-Sandoval Alcolea, A. (1996). Epidemic outbreak of 81 cases of brucellosis following the consumption of fresh cheese without pasteurization. Revista Española de Salud Pública, 70, 303-311. van Cauteren, D., Jourdan-da Silva, N., Weill, F. X., King, L., Brisabois, A., Delmas, G., et al. (2009). Outbreak of Salmonellaenterica serotype Muenster infections associated with goat's cheese, France, March 2008. Eurosurveillance, 14. Article 8.

CDC. (1983). Group C streptococcal infections associated with eating homemade cheese - New Mexico. Morbidity and Mortality Weekly Report, 32(510), 515-516.

CDC. (2000). Outbreak of Escherichia coli 0157:H7 infection associated with eating fresh cheese curds - Wisconsin, June 1998. Morbidity and Mortality Weekly Report, 49, 911-913.

CDC. (2001). Outbreak of listeriosis associated with homemade Mexican-style cheese - North Carolina, October 2000-January 2001. Morbidity and Mortality Weekly Report, 50, 560-562.

CDC. (2007). Salmonella Typhimurium infection associated with raw milk and cheese consumption - Pennsylvania, 2007. Morbidity and Mortality Weekly Report, 56, 1161-1164.

CDC. (2008). Outbreak of multidrug-resistant Salmonella enterica serotype Newport infections associated with consumption of unpasteurized Mexican-style aged cheese - Illinois, March 2006-April 2007. Morbidity and Mortality Weekly Report, 57, 432-435.

CDC. (2009). Campylobacter jejuni infection associated with unpasteurized milk and cheese - Kansas, 2007. Morbidity and Mortality Weekly Report, 57, 1377-1379.

CDC. (2014). Foodborne Outbreak Online Database (FOOD). Available online http:// wwwn.cdc.gov/foodborneoutbreaks/. Last accessed 07.07.14.

CDSC. (1998a). Cases of Escherichia coli 0157 infection associated with unpasteurised cream in England. Eurosurveillance, 2. Article 3.

CDSC. (1998b). Escherichia coli 0157 in Somerset. Communicable disease report. CDR Weekly, 8, 167.

Civera, T., Decastelli, L., Martorana, M., Dalmasso, A., Nucera, D., \& Bottero, M. T. (2007). Survey on the presence of enterovirulent Escherichia coli, including E. coli 0157, in cheese manufactured in the Italian Alpine Region. Italian Journal of Food Science, 19, 229-238.

Claeys, W. L., Cardoen, S., Daube, G., De Block, J., Dewettinck, K., Dierick, K., et al. (2013). Raw or heated cow milk consumption: review of risks and benefits. Food Control, 31, 251-262.

Claeys, W. L., Verraes, C., Cardoen, S., De Block, J., Huyghebaert, A., Raes, K., et al. (2014). Consumption of raw or heated milk from different species: an evaluation of the nutritional and potential health benefits. Food Control, 42, 188-201.

Cody, S. H., Abbott, S. L., Marfin, A. A., Schulz, B., Wagner, P., Robbins, K., et al. (1999) Two outbreaks of multidrug-resistant Salmonella serotype Typhimurium DT104 infections linked to raw-milk cheese in Northern California. Journal of the American Medical Association, 281, 1805-1810.

Coia, J. E., Johnston, Y., Steers, N. J., \& Hanson, M. F. (2001). A survey of the prevalence of Escherichia coli 0157 in raw meats, raw cow's milk and raw-milk cheeses in south-east Scotland. International Journal of Food Microbiology, 66, 63-69.

Conedera, G., Dalbit, P., Martini, M., Galiero, G., Gramaglia, M., Goffredo, E., et al. (2004). Verocytotoxin-producing Escherichia coli 0157 in minced beef and dairy products in Italy. International Journal of Food Microbiology, 96, 67-73.

Coveney, H. M., Fitzgerald, G. F., \& Daly, C. (1994). A study of the microbiologica status of Irish farmhouse cheeses with emphasis on selected pathogenic and spoilage micro-organisms. Journal of Applied Bacteriology, 77, 621-630.

Cremonesi, P., Perez, G., Pisoni, G., Moroni, P., Morandi, S., Luzzana, M., et al. (2007). Detection of enterotoxigenic Staphylococcus aureus isolates in raw milk cheese. Letters in Applied Microbiology, 45, 586-591.

Curnow, J. (1999). Escherichia coli 0157 outbreak in Scotland linked to unpasteurized goat's milk. Eurosurveillance, 3. Article 1387.

Dal Bello, B., Cocolin, L., Zeppa, G., Field, D., Cotter, P. D., \& Hill, C. (2012). Technological characterization of bacteriocin producing Lactococcus lactis strains employed to control Listeria monocytogenes in cottage cheese. International Journal of Food Microbiology, 153, 58-65.

Dalmasso, M., \& Jordan, K. (2014). Absence of growth of Listeria monocytogenes in naturally contaminated Cheddar cheese Journal of Dairy Research, 81, 46-53.

D'Amico, D. J., Druart, M. J., \& Donnelly, C. W. (2008). 60-Day aging requirement does not ensure safety of surface-mold-ripened soft cheeses manufactured from raw or pasteurized milk when Listeria monocytogenes is introduced as a postprocessing contaminant. Journal of Food Protection, 71, 1563-1571.

D'Amico, D. J., Druart, M. J., \& Donnelly, C. W. (2010). Behavior of Escherichia coli 0157:H7 during the manufacture and aging of Gouda and stirred-curd Cheddar cheeses manufactured from raw milk. Journal of Food Protection, 73, 2217-2224.

D'Aoust, J. Y., Warburton, D. W., \& Sewell, A. M. (1985). Salmonella Typhimurium phage-type 10 from Cheddar cheese in a major Canadian foodborne outbreak. Journal of Food Protection, 48, 1062-1066.

Da Silva, F. M. T., Hald, T., Liebana, E., Allende, A., Hugas, M., Nguyen-The, C., et al (2015). Risk ranking of pathogens in ready-to-eat unprocessed foods of nonanimal origin (FoNAO) in the EU: initial evaluation using outbreak data (2007-2011). International Journal of Food Microbiology, 195, 9-19.

De Buyser, M.-L., Dufour, B., Maire, M., \& Lafarge, V. (2001). Implication of milk and milk products in food-borne diseases in France and in different industrialized countries. International Journal of Food Microbiology, 67, 1-17.

De Buyser, M.-L., Janin, F., \& Dilasser, F. (1985). Contamination of ewe cheese with Staphylococcus aureus: study of an outbreak of food poisoning. Zentralblatt für Bakteriologie, Mikrobiologie und Hygiene, 14, 677.

Decludt, B. (1995). Cas groupés de syndromes hémolytiques et urémiques dans le département de l'Ardèche en 1994. Saint-Maurice, France: Institut de Veille Sanitaire. 
De Reu, K., Debeuckelaere, W., Botteldoorn, N., De Block, J., \& Herman, L. (2002) Hygienic parameters, toxins and pathogen occurrence in raw milk cheeses. Journal of Food Safety, 22, 183-196.

De Reu, K., Grijspeerdt, K., \& Herman, L. (2004). A Belgian survey of hygiene indicator bacteria and pathogenic bacteria in raw milk and direct marketing of raw milk farm products. Journal of Food Safety, 24, 17-36.

De Reu, K., \& Herman, L. (2004). Rapport 2003-2004 'Aanwezigheid en overleving van Listeria monocytogenes in rauwmelkse hoeveboter'. Source: ILVO-T\&V.

De Reu, K., Herman, L., De Boosere, I., \& De Ville, W. (2006). Rapport 2006 'Aanwezigheid en aantallen van Listeria monocytogenes in Belgische hoeveboter' Rapport Listeria in hoeveboter. Source: ILVO-T\&V.

De Reu, K., Herman, L., De Boosere, I., \& De Ville, W. (2007). Rapport 2007 'Aanwezigheid en aantallen van Listeria monocytogenes in Belgische hoeveboter'.Rapport Listeria in hoeveboter. Source: ILVO-T\&V.

De Reu, K., Herman, L., \& De Ville, W. (2008). Rapport 2008 'Aanwezigheid en aantallen van Listeria monocytogenes in Belgische hoeveboter'. Rapport Listeria in hoeveboter. Source: ILVO-T\&V.

De Valk, H., Delarocque-Astagneau, E., Colomb, G., Ple, S., Godard, E., Vaillant, V., et al. (2000). A community-wide outbreak of Salmonella enterica serotype Typhimurium infection associated with eating a raw milk soft cheese in France. Epidemiology and Infection, 124, 1-7.

Delcenserie, V., Taminiau, B., Delhalle, L., Nezer, C., Doyen, P., Crevecoeur, S., et al. (2014). Microbiota characterization of a Belgian protected designation of origin cheese, Herve cheese, using metagenomic analysis. Journal of Dairy Science, 97 $1-11$.

Desenclos, J.-C., Bouvet, P., Benz-Lemoine, E., Grimont, F., Desqueyroux, H., Rebière, I., et al. (1996). Large outbreak of Salmonella enterica serotype Paratyphi B infection caused by a goats' milk cheese, France, 1993: a case finding and epidemiological study. British Medical Journal, 312, 91-94.

EFSA. (2013a). Scientific opinion on the risk posed by pathogens in food of nonanimal origin. Part 1 (outbreak data analysis and risk ranking of food/pathogen combinations). EFSA Journal, 11, 3025.

EFSA. (2013b). Analysis of the baseline survey on the prevalence of Listeria monocytogenes in certain ready-to-eat foods in the EU, 2010-2011 part A: Listeria monocytogenes prevalence estimates. EFSA Journal, 11, 3241.

EFSA. (2015). Scientific opinion on the public health risks related to the consumption of raw drinking milk. EFSA Journal, 13, 3940.

EFSA, \& ECDC. (2014). The European summary report on trends and sources of zoonoses, zoonotic agents and food-borne outbreaks in 2012. EFSA Journal, 12 3547.

EFSA, \& ECDC. (2015). The European summary report on trends and sources of zoonoses, zoonotic agents and food-borne outbreaks in 2013. EFSA Journal, 12, 3547.

Elbers, A. R. W., Miltenburg, J. D., De Lange, D., Crauwels, A. P. P., Barkema, H. W., \& Schukken, Y. H. (1998). Risk factors for clinical mastitis in a random sample of dairy herds from the southern part of the Netherlands. Journal of Dairy Science, $81,420-426$

Eldin, C., Angelakis, E., Renvoisé, A., \& Raoult, D. (2013). Coxiella burnetii DNA, but not viable bacteria, in dairy products in France. American Journal of Tropical Medicine and Hygiene, 88, 765-769.

Ellis, A., Preston, M., Borczyk, A., Miller, B., Stone, P., Hatton, B., et al. (1998). A community outbreak of Salmonella berta associated with a soft cheese product. Epidemiology and Infection, 120, 29-35.

Espié, E., Vaillant, V., Mariani-Kurkdjian, P., Grimont, F., Martin-Schaller, R., de Valk, H., et al. (2006). Escherichia coli 0157 outbreak associated with fresh unpasteurized goats' cheese. Epidemiology and Infection, 134, 143-146.

Fach, P., Perelle, S., Dilasser, F., \& Grout, J. (2001). Comparison between a PCR-ELISA test and the vero cell assay for detecting Shiga toxin-producing Escherichia coli in dairy products and characterization of virulence traits of the isolated strains. Journal of Applied Microbiology, 90, 809-818.

Farrokh, C., Jordan, K., Auvray, F., Glass, K., Oppegaard, H., Raynaud, S., et al. (2013). Review of Shiga-toxin-producing Escherichia coli (STEC) and their significance in dairy production. International Journal of Food Microbiology, 162, 190-212.

FASFC, WIV, \& CODA. (2011). Working group on foodborne infections and intoxications. Available online http://www.coda-cerva.be/images/pdf/trends\% 20and\%20sources\%202010-2011.pdf. Last accessed 13.10.14.

Frece, J., Markov, K., Čvek, D., Kolarec, K., \& Delaš, F. (2010). Comparison of conventional and molecular methods for the routine confirmation of Listeria monocytogenes in milk products produced domestically in Croatia. Journal of Dairy Research, 77, 112-116.

van Gastelen, S., Westerlaan, B., Houwers, D. J., \& van Eerdenburg, F. J. C. M (2011). A study on cow comfort and risk for lameness and mastitis in relation to different types of bedding materials. Journal of Dairy Science, 94, 4878-4888.

Gaulin, C., Levac, E., Ramsay, D., Dion, R., Ismaïl, J., Gingras, S., et al. (2012) Escherichia coli 0157:H7 outbreak linked to raw milk cheese in Quebec, Canada: use of exact probability calculation and case-case study approaches to foodborne outbreak Investigation. Journal of Food Protection, 75, 812-818.

Gould, L. H., Mungai, E., \& Behravesh, C. B. (2014). Outbreaks attributed to cheese: differences between outbreaks caused by unpasteurized and pasteurized dairy products, United States, 1998-2011. Foodborne Pathogens and Disease, 11, $545-551$.

Greenwood, M. H., Roberts, D., \& Burden, P. (1991). The occurrence of Listeria species in milk and dairy products: a national survey in England and Wales. International Journal of Food Microbiology, 12, 197-206.
Grimont, P. A. D., \& Bouvet, P. (1991). Les salmonelles et les shigelles en 1990 en France. Bulletin Epidémiologique Hebdomadaire, 15, 102.

Haeghebaert, S., Sulem, P., Deroudille, L., Vanneroy-Adenot, E., Bagnis, O., Bouvet, P., et al. (2003). Two outbreaks of Salmonella Enteritidis phage type 8 linked to the consumption of Cantal cheese made with raw milk, France, 2001. Eurosurveillance, 8. Article 1.

Hahn, G., Walte, H. G., Coenen, C., \& Teufel, P. (1999a). Direktvermarktung von Produkten aus Rohmilch: Befunde und Risikoerörterung. Kieler Milchwirtschaftliche Forschungsberichte, 51, 333-342.

Hahn, G., Walte, H. G., Coenen, C., \& Teufel, P. (1999b). Direktvermarktung von Rohmilch: Befunde und Risikoerörterung. Kieler Milchwirtschaftliche Forschungsberichte, 51, 105-115.

Halasa, T., Huijps, K., Osteras, O., \& Hogeveen, H. (2007). Economic effects of bovine mastitis and mastitis management: a review. Veterinary Quarterly, 29, 18-31.

Holzmann, H., Aberle, S. W., Stiasny, K., Werner, P., Mischak, A., Zainer, B., et al. (2009). Tick-borne encephalitis from eating goat cheese in a mountain region of Austria. Emerging Infectious Diseases, 15, 1671-1673.

Honish, L., Predy, G., Hislop, N., Chui, L., Kowalewska-Grochowska, K., Trottier, L., et al. (2005). An outbreak of E. coli 0157:H7 hemorrhagic colitis associated with unpasteurized Gouda cheese. Revue Canadienne de Santé Publique, 96, 182-184.

Huchot, B., Bohnert, M., Cerf, O., Farrokh, C., \& Lahellec, C. (1993). Does cheese made of raw milk represent a public health problem? A review of international epidemiological data. International Dairy Federation, 48. F-doc 223 supplement.

Infuso, A., Vaillant, V., \& Desenclos, J. C. (1997). Epidémie de salmonellose à Salmonella enterica sérotype Dublin, France, November-December 1996. Saint-Maurice, France: Institut de Veille Sanitaire.

INVS. (2007). Epidémie d'infections à E. coli producteurs de Shiga-toxines non 0157 liée à la consommation de Camambert au lait cru, nord-ouest de la France, octobre-décembre 2005. Available online http://www.invs.sante.fr/ publications/2008/epidemie_e_coli_camembert/rapport_epidemie_stec.pdf. Last accessed 07.07.14.

Jacquet, C., Saint-Cloment, C., Brouille, F., Catimel, B., \& Rocourt, J. (1998). La listeriose humaine en France en 1997, données du Centre National de Référence des Listeria. Bulletin Epidémiologique Hebdomadaire, 33, 142-143.

Jakobsen, R. A., Heggebø, R., Sunde, E. B., \& Skjervheim, M. (2011). Staphylococcus aureus and Listeria monocytogenes in Norwegian raw milk cheese production. Food Microbiology, 28, 492-496.

Jørgensen, H. J., Mørk, T., \& Rørvik, L. M. (2005). The occurrence of Staphylococcus aureus on a farm with small-scale production of raw milk cheese. Journal of Dairy Science, 88, 3810-3817.

Kongo, J. M., Malcata, F. X., Ho, A. J., \& Wiedmann, M. (2006). Detection and characterization of Listeria monocytogenes in São Jorge (Portugal) cheese production. Journal of Dairy Science, 89, 4456-4461.

Kř́iž, B., Beneš, C., \& Daniel, M. (2009). Alimentary transmission of tick-borne encephalitis in the Czech Republic (1997-2008). Epidemiologie, Mikrobiologie, Imunologie, 58, 98-103.

Leuschner, R. G. K., \& Ielsch, V. (2003). Antimicrobial effects of garlic, clove and red hot chilli on Listeria monocytogenes in broth model systems and soft cheese. International Journal of Food Sciences and Nutrition, 54, 127-133.

Loncarevic, S., Danielsson-Tham, M. L., \& Tham, W. (1995). Occurrence of Listeria monocytogenes in soft and semi-soft cheeses in retail outlets in Sweden. International Journal of Food Microbiology, 26, 245-250.

MacDonald, P. D. M., Whitwam, R. E., Boggs, J. D., MacCormack, J. N., Anderson, K. L., Reardon, J. W., et al. (2005). Outbreak of listeriosis among Mexican immigrants as a result of consumption of illicitly produced Mexican-style cheese. Clinical Infectious Diseases, 40, 677-682.

Madic, J., Vingadassalon, N., Peytavin de Garam, C., Marault, M., Scheutz, F., Brugère, H., et al. (2011). Detection of Shiga toxin-product in Escherichia coli serotypes 026:H11, 0103:H2, 0111:H8, 0145:H28, and 0157:H7 in raw-milk cheeses by using multiplex real-time PCR. Applied and Environmental Microbiology, 77, 2035-2041.

Magnusson, M., Christiansson, A., Svensson, B., \& Kolstrup, C. (2006). Effect of different premilking manual teat-cleaning methods on bacterial spores in milk. Journal of Dairy Science, 89, 3866-3875.

Maguire, H. C. F., Boyle, M., Lewis, M. J., Pankhurst, J., Wieneke, A. A., Jacob, M., et al. (1991). A large outbreak of food poisoning of unknown aetiology associated with Stilton cheese. Epidemiology and Infection, 109, 497-505.

Maguire, H., Cowden, J., Jacob, M., Rowe, B., Roberts, D., Bruce, J., et al. (1992). An outbreak of Salmonella dublin infection in England and Wales associated with a soft unpasteurized cow's milk cheese. Epidemiology and Infection, 109, 389-396.

Magwedere, K., Bishi, A., Tjipura-Zaire, G., Eberle, G., Hemberger, Y., Hoffman, L. C., et al. (2011). Brucellae through the food chain: the role of sheep, goats and springbok (Antidorcus marsupialis) as sources of human infections in Namibia. Journal of the South African Veterinary Association, 82, 205-212.

Maher, M. M., Jordan, K. N., Upton, M. E., \& Coffey, A. (2001). Growth and survival of E. coli 0157:H7 during the manufacture and ripening of a smear-ripened cheese produced from raw milk. Journal of Applied Microbiology, 90, 201-207.

MAPAQ. (2004). Mise en garde - Onze personnes malades à la suite de la consommation de fromages au lait cru fabriqués à la ferme. Press Release, 14 July 2004.

Masoud, W., Vogensen, F. K., Lillevang, S., Al-Soud, W. A., Sørensen, S. J., \& Jakobsen, M. (2012). The fate of indigenous microbiota, starter cultures, Escherichia coli, Listeria innocua and Staphylococcus aureus in Danish raw milk and cheeses determined by pyrosequencing and quantitative real time (qRT)PCR. International Journal of Food Microbiology, 153, 192-202. 
McCollum, J. T., Williams, N. J., Beam, S. W., Cosgrove, S., Ettestad, P. J., Ghosh, T. S., et al. (2012). Multistate outbreak of Escherichia coli 0157:H7 infections associated with in-store sampling of an aged raw-milk Gouda cheese, 2010. Journal of Food Protection, 75, 1759-1765.

Méndez-González, K. Y., Hernández-Castro, R., Carrillo-Casas, E. M., Monroy, J. F., López-Merino, A., \& Suárez-Güemes, F. (2011). Brucella melitensis survival during manufacture of ripened goat cheese at two temperatures. Foodborne Pathogens and Disease, 8, 1257-1261.

Méndez Martínez, C., Páez Jiménez, A., Cortés Blanco, M., Salmoral Chamizo, E. Mohedano Mohedano, E., Plata, C., et al. (2003). Brucellosis outbreak due to unpasteurized raw goat cheese in Andalucia (Spain), January-March 2002. Eurosurveillance, 8, 164-168.

Messelhäusser, U., Beck, H., Gallien, P., Schalch, B., \& Busch, U. (2008). Presence of Shiga toxin-producing Escherichia coli and thermophilic Campylobacter spp. in cattle, food and water sources on Alpine pastures in Bavaria. Archiv für Lebensmittelhygiene, 59, 103-106.

Miszczycha, S. D., Perrin, F., Ganet, S., Jamet, E., Tenenhaus-Aziza, F., Montel, M.-C., et al. (2013). Behavior of different Shiga toxin-producing Escherichia coli serotypes in various experimentally contaminated raw-milk cheeses. Applied and Environmental Microbiology, 79, 150-158.

Miszczycha, S. D., Thévenot, J., Denis, S., Callon, C., Livrelli, V., Alric, M., et al. (2014). Survival of Escherichia coli O26:H11 exceeds that of Escherichia coli 0157:H7 as assessed by simulated human digestion of contaminated raw milk cheeses. International Journal of Food Microbiology, 172, 40-48.

Montet, M. P., Jamet, E., Ganet, S., Dizin, M., Miszczycha, S., Dunière, L., et al. (2009). Growth and survival of acid-resistant and non-acid-resistant Shigatoxin-producing Escherichia coli strains during the manufacture and ripening of Camembert cheese. International Journal of Microbiology, 2009. Article 653481.

Ostyn, A., De Buyser, M.-L., Guillier, F., Groult, J., Félix, B., Salah, S., et al. (2010). First evidence of a food poisoning outbreak due to staphylococcal enterotoxin type E., France, 2009. Eurosurveillance, 15. Article 3.

Peng, S., Hoffmann, W., Bockelmann, W., Hummerjohann, J., Stephan, R., \& Hammer, P. (2013). Fate of Shiga toxin-producing and generic Escherichia coli during production and ripening of semihard raw milk cheese. Journal of Dairy Science, 96, 815-823.

Pintado, C. M., Grant, K. A., Halford-Maw, R., Hampton, M. D., Ferreira, M. A., \& McLauchlin, J. (2009). Association between a case study of asymptomatic ovine listerial mastitis and the contamination of soft cheese and cheese processing environment with Listeria monocytogenes in Portugal. Foodborne Pathogens and Disease, 6, 569-575.

Plommet, M., Fensterbank, R., Vassal, L., Auclair, J., Mocquot, G., Vachot, J. C., et al. (1988). Survival of Brucella abortus in ripened soft cheese made from naturally infected cow's milk. Lait, 68, 115-120.

Poli, A., Guglielmini, E., Sembeni, S., Spiazzi, M., Dellaglio, F., Rossi, F., et al. (2007). Detection of Staphylococcus aureus and enterotoxin genotype diversity in Monte Veronese, a protected designation of origin Italian cheese. Letters in Applied Microbiology, 45, 529-534.

Rahimi, E., Doosti, A., Ameri, M., Kabiri, E., \& Sharifian, B. (2008). Detection of Coxiella burnetii by nested PCR in bulk milk samples from dairy bovine, ovine, and caprine herds in Iran. Zoonoses and Public Health, 57, 38-41.

Ramsaran, H., Chen, J., Brunke, B., Hill, A., \& Griffiths, M. W. (1998). Survival of bioluminescent Listeria monocytogenes and Escherichia coli 0157:H7 in soft cheeses. Journal of Dairy Science, 81, 1810-1817.

Rantsiou, K., Alessandria, V., Urso, R., Dolci, P., \& Cocolin, L. (2008). Detection, quantification and vitality of Listeria monocytogenes in food as determined by quantitative PCR. International Journal of Food Microbiology, 121, 99-105.

Rosengren, Å., Fabricius, A., Guss, B., Sylvén, S., \& Lindqvist, R. (2010). Occurrence of foodborne pathogens and characterization of Staphylococcus aureus in cheese produced on farm-dairies. International Journal of Food Microbiology, 144, 263-269.

Sahebekhtiari, N., Nochi, Z., Eslampour, M. A., Dabiri, H., Bolfion, M., Taherikalani, M., et al. (2011). Characterization of Staphylococcus aureus strains isolated from raw milk of bovine subclinical mastitis in Tehran and Mashhad. Acta Microbiologica et Immunologica Hungarica, 58, 113-121.

Schlesser, J. E., Gerdes, R., Ravishankar, S., Madsen, K., Mowbray, J., \& Teo, A. Y. (2006). Survival of a five-strain cocktail of Escherichia coli 0157:H7 during the 60 -day aging period of Cheddar cheese made from unpasteurized milk. Journal of Food Protection, 69, 990-998.

Schoder, D., Melzner, D., Schmalwieser, A., Zangana, A., Winter, P., \& Wagner, M. (2011). Important vectors for Listeria monocytogenes transmission at farm dairies manufacturing fresh sheep and goat cheese from raw milk. Journal of Food Protection, 74, 919-924.

Schoder, D., Winter, P., Kareem, A., Baumgartner, W., \& Wagner, M. (2003). A case of sporadic ovine mastitis caused by Listeria monocytogenes and its effect on contamination of raw milk and raw-milk cheeses produced in the on-farm dairy. Journal of Dairy Research, 70, 395-401.

Schukken, Y. H., Grommers, F. J., Vandegeer, D., Erb, H. N., \& Brand, A. (1990). Riskfactors for clinical mastitis in herds with a low bulk milk somatic-cell count. 1. Data and risk-factors for all cases. Journal of Dairy Science, 73, 3463-3471.

Schvartzman, M. S., Maffre, A., Tenenhaus-Aziza, F., Sanaa, M., Butler, F., \& Jordan, K. (2011). Modelling the fate of Listeria monocytogenes during manufacture and ripening of smeared cheese made with pasteurised or raw milk. International Journal of Food Microbiology, 145, S31-S38.

Sci Com. (2010a). Advice 24-2010 of 18 June 2010 of the Scientific Committee of the FASFC on the evaluation of a program for surveillance, prevention and control of Coxiella burnetii in small ruminants (dossier Sci Com 2010/11). Available online http://www.favv-afsca.fgov.be/wetenschappelijkcomite/adviezen/_documents/ ADVIES24-2010_NL_DOSSIER2010-11.pdf. Last accessed 13.10.14.

Sci Com. (2010b). Advice 25-2010 of 18 June 2010 of the Scientific Committee of the FASFC on the surveillance, prevention and control of Coxiella burnetii in cattle (dossier Sci Com 2010/12). Available online http://www.favv-afsca.fgov.be/ wetenschappelijkcomite/adviezen/_documents/ADVIES25-2010_NL_ DOSSIER2010-12.pdf. Last accessed 13.10.14.

Sci Com. (2011). Advice 15-2011 of 14 October 2011 of the Scientific Committee of the FASFC on the risk-benefit evaluation of raw cow milk consumption and the effect of heat treatment on these risks and benefits. Available online http://www.favvafsca.fgov.be/wetenschappelijkcomite/adviezen/_documents/ADVIES15-2011 NL_DOSSIER2010-25.pdf. Last accessed 13.10.14.

Sci Com. (2013). Advice 11-2013 of 22 March 2013 of the Scientific Committee of the FASFC on the evaluation of the risks and benefits of the consumption of raw milk from animal species other than cows. Available online http://www.favv-afsca. fgov.be/wetenschappelijkcomite/adviezen/_documents/ADVIES11-2013_NL_ DossierSciCom2012-12.pdf. Last accessed 13.10.14.

Sci Com. (2015). Advice 02-2015 of 27 February 2015 of the Scientific Committee of the FASFC on the evaluation of the microbiological risks of the consumption of dairy products based on raw milk. Available online http://www.favv-afsca.fgov.be/ wetenschappelijkcomite/adviezen/_documents/ADVIES02-2015_NL_DOSSIER_ 2014-06.pdf. Last accessed 31.03.15.

Spahr, U., \& Schafroth, K. (2001). Fate of Mycobacterium avium subsp. paratuberculosis in Swiss hard and semihard cheese manufactured from raw milk Applied and Environmental Microbiology, 67(9), 4199-4205.

Spano, G., Goffredo, E., Beneduce, L., Tarantino, D., Dupuy, A., \& Massa, S. (2003) Fate of Escherichia coli 0157:H7 during the manufacture of Mozzarella cheese. Letters in Applied Microbiology, 36, 73-76.

Stephan, R., Schumacher, S., Corti, S., Krause, G., Danuser, J., \& Beutin, L. (2008). Prevalence and characteristics of Shiga toxin-producing Escherichia coli in Swiss raw milk cheeses collected at producer level. Journal of Dairy Science, 91 2561-2565.

Stephan, R., Schumaher, S., Tasara, T., \& Grant, I. R. (2007). Prevalence of Mycobacterium avium subspecies paratuberculosis in Swiss raw milk cheeses collected at the retail level. Journal of Dairy Science, 90, 3590-3595.

Strachan, N. J. C. Dunn, G. M., Mary, E., Locking, M. E., Reis, T. M. S., \& Ogden, I. D. (2006). Escherichia coli 0157: burger bug or environmental pathogen? International Journal of Food Microbiology, 112, 129-137.

Trevisani, M., Mancusi, R., \& Valero, A. (2014). Thermal inactivation kinetics of Shiga toxin-producing Escherichia coli in buffalo Mozzarella curd. Journal of Dairy Science, 97, 642-650.

Vaillant, V., Haeghebaert, S., Desenclos, J. C., Bouvet, P., Grimont, F., Grimont, P. A., et al. (1996). Outbreak of Salmonella dublin infection in France, November-December 1995. Eurosurveillance, 1. Article 1.

Vaillant, V., Maillot, E., Charley, C., \& Stainer, F. (1998). Epidémie de listeriose, France, avril-aout 1995. Saint-Maurice, France: Institut de Veille Sanitaire.

Valero, A., Hernandez, M., De Cesare, A., Manfreda, G., González-García, P., \& Rodríguez-Lázaro, D. (2014). Survival kinetics of Listeria monocytogenes on raw sheep milk cured cheese under different storage temperatures. International Journal of Food Microbiology, 184, 39-44.

Vernozy-Rozand, C., Montet, M. P., Berardin, M., Bavai, C., \& Beutin, L. (2005). Isolation and characterization of Shiga toxin-producing Escherichia coli strains from raw milk cheeses in France. Letters in Applied Microbiology, 41, 235-241.

Verraes, C., Claeys, W., Cardoen, S., Daube, G., De Zutter, L., Imberechts, H., et al. (2014). A review of the microbiological hazards of raw milk from animal species other than cows. International Dairy Journal, 39, 121-130.

Villar, R. G., Macek, M. D., Simons, S., Hayes, P. S., Goldoft, M. J., Lewis, S. H., et al. (1999). Investigation of the multidrug-resistant Salmonella serotype Typhimurium DT104 infections linked to raw-milk cheese in Washington state. Journal of the American Medical Association, 281, 1811-1816.

Volponi, G., Rooks, D. J., Smith, D. L., Picozzi, C., Allison, H. E., Vigentini, I., et al. (2012). Short communication: characterization of Shiga toxin 2-carrying bacteriophages induced from Shiga-toxigenic Escherichia coli isolated from Italian dairy products. Journal of Dairy Science, 95, 6949-6956.

Whyte, P., McGill, K., Cowley, D., Madden, R. H., Moran, L., Scates, P., et al. (2004). Occurrence of Campylobacter in retail food in Ireland. International Journal of Food Microbiology, 95, 111-118.

Williams, A. G., \& Withers, S. E. (2010). Microbiological characterisation of artisanal farmhouse cheeses manufactured in Scotland. International Journal of Dairy Technology, 63, 356-369.

Wood, D. S., Collins-Thompson, D. L., Irvine, D. M., \& Muhr, A. N. (1984). Source and persistence of Salmonella Muenster in naturally contaminated Cheddar cheese. Journal of Food Protection, 47, 20-22.

Zweifel, C., Giezendanner, N., Corti, S., Krause, G., Beutin, L., Danuser, J., et al. (2010). Characteristics of Shiga toxin-producing Escherichia coli isolated from Swiss raw milk cheese within a 3-year monitoring program. Journal of Food Protection, 73, 88-91. 